\title{
Desa Putukrejo, Malang Selatan : Suatu Pembahasan Tentang Motivasi
}

Oleh : Prof.Dr.H.A. Mukti Ali

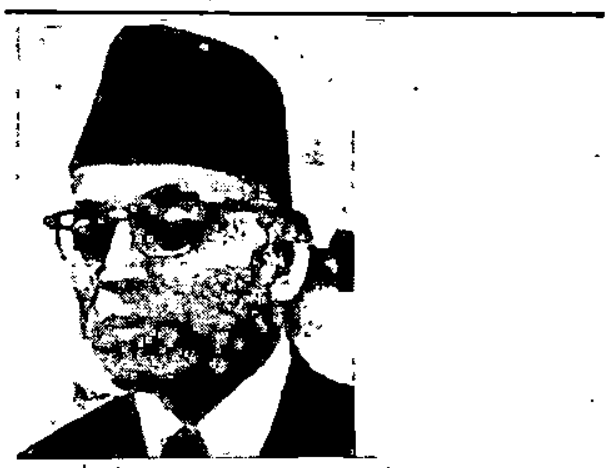

Prof.Dr.HA Mukt। All adalah bèkas Menteri Agama Republik indonesia (1971-1978) yang kini secara tetap menjadi Guru Besar (llmu Perbandingan Agama) IAIN Sunan Kalijaga Yogyakarta. Dilahirkan di Ceju Jawa Tengah pada tahun 1923 dengan name Soedjono kemudian masuk lembaga pendidikan melalui Pondok Pesantren Tremas dan di Pondok inilah nama aslinya, Soedjono, diganti dengan Muktl Ali. Memperoleh gelar M.A. deri Faculty of Devinity \& Islamic Studies, Mc Gill University-Kanada, kemudian memperoleh gelar doktor dari Universitas Karachi - Pakistan. Sebelum menjadi Menteri Agama pernah menjadi Pegawai jawatan Pendidikan Agama, Pembantu Sekjen Departemen Agama, dosen dan dekan Fakultás Ushuludin. IAIN Sunan Kalijaga Yogyakarta. Sekarang juga menjadi.anggota DPA - RI dan anggota Sidang Pleno Badan Wakaf UII.

\section{PEMBUKA KATA}

Beberapa tahun yang lalu, kalau tidak salah pada tahun 1974, saya pernah membaca di salah satu surat kabar harian di Jakarta tentang suatu desa di Malang Selatan, Putukrejo namanya, yang berhasil membangun desanya dengan penerapan zakat. Pemberitaan jurnalistik itu sangat menarik perhatian saya.

Seläin pada tahun 1979 Dewan Pertimbangan Agung menetapkan rencana kerja mengadakañ peninjauan ke daerah-daerah, saya mengajukan rencana kepada Komisi IV, Bidang Kesejahteraan Rakyat, untuk mengadakan survei selama tiga bulan ke desa Putukrejo itu. Maksüd survei itu adalah untuk meneliti desa Putukrejo secara keseluruhan dengan menganggap desa itu sebagai satu unit sosial. Dengan studi kasus itu saya berharap bisa melakukan penelitian secara mendalam dan rinci. Segala aspek desa Putukrejo itu akan mendapat perhatian sepenuhnya. Dalam hal pembangunan desa Putukrejo yang dilakukan dengan pemungutan zakat, akan diteliti tentang terjadinya zakat, perkembangan dan perubahan-perubahan yang terjadi dalam masyarakat seba- 
gai akibat dari pelaksanaan zakat itu. Dengan itu diharapkan dapat memperlihatkan kebulatan dan keseluruhan desa Putukrejo dan keseluruhan interaksi faktor-faktor dalam kasus desa Putukrejo.

Usul itu segera mendapat persetujuan Ketua Komisi IV. Tetapi kemudian ternyata studi kasus yang akan memakan waktu tiga bulan itu tidak dapat dilaksanakan karena tidak ada biaya. Akhirnya toh penelitian saya lakukan dengan biaya seadanya, yaitu pada bulan Oktober, selama 10 hari, November, selama 5 hari dan Desember 1979, selama 5 hari. Untuk pengumpulan bahan, saya dibantu oleh dua orang staf DPA, yaitu Sdr. Hanif Adams, B.Sc. yang mengumpulkan bahan yang berhubungan dengan aspek politik, pemerintah dan sosial, Sdr. Drs. Bambang Wijoyoko tentang aspek-aspek ekonomi, ditambah dengan seorang dosen Fakultas Ushuluddin IAIN Sunan Kalijaga Yogyakarta, Sdr. Drs. Abdurrahman tentang aspek agama dan sosial.

Dalam usaha memperoleh keterangan sebanyak-banyaknya dalam waktu yang sesingkat-singkatnya itu, maka jauh sebelumnya bahan-bahan yang akan dicari dan permasalahan-permasalahan yang akan dibahas sudah dipersiapkan terlebih dahulu. Dan sewaktu benarbenar terjun ke desa Putukrejo, cara "partisipasi" dengan masyarakat desa benar-benar dilakukan. Karena masyarakat Putukrejo, sebagaimana nanti akan diterangkan, adalah seluruhnya Muslim, maka selain memakai cara wawancara, diskusi, dan sebagainya, saya juga memberikan ceramah agama, menjadi imam shalat Maghrib dan tahlil di Masjid Jami' desa Putukrejo.
. Untuk menambah keterangan dan memeriksa kebenaran interpretasi tentang fakta yang diperoleh, maka selain hasil survei itu dirembug di Putukrejo, juga saya adakan diskusi dengan Pemerintah Daerah Kabupaten Malang yang dihadiri juga oleh beberapa dosen dari Universitas Brawijaya dan Fakultas Tarbiyah IAIN Sunan Ampel Malang. Selain itu hasil survei juga saya diskusikan dengan Pemerintah Daerah Provinsi Jawa Timur bersama-sama dengan instansi-instansi Pemerintah Tingkat Provinsi, seperti Perkoperasian, Transmigarsi, Perindustrian, Departemen Agama, dan beberapa dosen dari Fakultas Ekonomi Universitas Airlangga di Surabaya. Berikutnya lalu saya diskusikan dengan Kelompok Diskusi Dosendosen IAIN Sunan Kalijaga Yogyakarta, yang juga dihadiri oleh beberapa dosen dari Lembaga Studi Pedesaan Universitas Gadjah Mada, beberapa dosen Fakultas Ekonomi Gadjah Mada dan Fakultas Ekonomi Universitas Islam Indonesia di Yogyakarta: Semua diskusi dilaksanakan pada bulan Desember 1979.

Untuk mendapatkan data yang lengkap tentang desa Putukrejo, saya kira memerlukan waktu tidak kurang dari tiga bulan di lapangan, karena data itu baru bisa diperoleh dengan benar-benar terjun di masyarakat. Sungguhpun demikian, dengan bahan-bahan yang sangat sedikit, saya memberanikan diri mencoba untuk memberikan interpretasi tentang fakta-fakța yang ditemukan di desa Putukrejo, dengan harapan dapat dilengkapi oleh penelitian-penelitian yang akan datang.

Survei yang dilakukan tidak mungkin terlaksana tanpa bantuan dan keramah- 
an banyak pihak, yang rasa-rasanya sangat sulit untuk disebutkan satu demi satu. Sungguhpun demikian adalah pada tempatnya, di sini saya mengucapkan terimakasih yang sebesar-besarnya kepada Lurah/Kepala desa Putukrejo dengan para pamong desanya, para alim-ulama dan pemimpin-pemimpin di desa itu; kepada Camat Gondanglegi dan stafnya; kepada Bupati/Kepala Daerah Kabupaten Malang dengan stafnya, Fakultas Ekonomi Universitas Brawijaya dan IAIN Sunan Ampel Malang; kepada Gubernur/Kepala Daerah Provinsi Jawa Timur dan Instansi-instansi Pemerintah Daerah tingkat Provinsi, juga kepada Fakultas Ekonomi Universitas Airlangga; kepada IAIN Sunan Kalijaga, Lembaga Studi Pedesaan Universitas Gadjah Mada, Fakultas Ekonomi Universitas Islam Indonesia Yogyakarta, atas segala bantuan bantuan dan keramahan yang diberikan kepada saya dan staf sewaktu melaksanakan survei dan diskusi di tempat-tempat tersebut.

Mudah-mudahan Allah SWT memberi balasan atas amal kebaikan mereka itu. Amin.

\section{PETA DESA PUTUKREJO}

\section{Pendahuluan}

Desa Putukrejo terletak pada dataran yang subur, yang luasnya sekitar $3,67 \mathrm{~km}^{2}$ dan berpenduduk sebanyak \pm 2870 jiwa. Mata pencaharian utama adalah bertani dengan mengusahakan tanaman tebu di samping padi dan palawija.

Mengingat seluruh penduduknya beragama Islam, maka desa ini mempunyai banyak alim-ulama yang cukup berpengaruh sebagai pimpinan masyarakat dan telah dapat menggalang kesatuan rakyat setempat untuk pembangunan.

Seusai Perang Dunia II para alim-ulama yang sudah sejak lama merupakan tokoh masyarakat, aktif menjalankan peranan sebagai pembina dan penggerak masyarakat dengan cara mengkoordinasi dan mengatur péngajian-pengajian di tiap-tiap RT, bergilir dari rumah ke rumāh, yang melibatkan segenap unsur masyarakat setempat baik orang tua, pemuda, anak-anak, pria maupun wanita. Kegiatan seperti ini tidak saya dilakukan di bidang keagamaan, tetapi juga di bidang-bidang kehidupan lainnya, sehingga dengan demikian kelihatan para warga desa benar-benar berpartisipasi dalam kehidupan masyarakat. Kebiasaan ini tetap berlangsung sampai kurun pembangunan desa ini dan inilah pula yang telah mendorong rasa kesatuan para warga masyarakat dalam setiap kegiatan bagi kepentingan bersama yang pada gilirannya mengokohkan sikap kerja sama yang kompak antar pimpinan desa, para alim-ulama dan masyarakat. Keberhasilan para pemuka desa Putukrejo membangkitkan swadaya masyarakat dalam menghadapi masalah-masalah pembangunan merupakan contoh konkrit dari satu model pembangunan yang mengambil titik-tolak usahanya dari masalah rakyat kecil di tingkat paling bawah, yaitu masyarakat tani di pedesaan.

Adalah menarik sekali untuk diungkapkan semangat gotong-royong masyarakat desa ini, terutama karena motivasi yang digunakan adalah nilainilai budaya, lembaga-lembaga agama dan tradisi yang telah berakar dalam masyarakat; yaitu dengan cara mengajak masyarakat mengenal masalah 
sekitar mereka yang sedang dihadapi serta membantu mereka mengorganisasi dirinya sendiri guna mencari pemecahan yang sesuai dengan kemampuan dan situasi setempat. Hal ini telah mendorong rasa tanggung jawab para warga desa terhadap kesejahteraan desanya. Tampaknya pimpinan masyarakat desa di sini secara cermat, berdasarkan etik, moral dan ajaran agama, mampu memberi interpretasi, membimbing, menunjukkan teladan secara konkrit terhadap berbagai persoalan nyata dan aktual yang dihadapi masyarakat.

Desa Putukrejo berada pada ketinggian $\pm 356 \mathrm{~m}$ dari permukaan laut dan terletak $17 \mathrm{~km}$ di sebelah Selatan kota Malang atau $6 \mathrm{~km}$ ke utara dari ibukota kecamatannya, Gondanglegi. Desa ini dikelilingi oleh beberapa desa, yaitu desa Gading di sebelah utara, Desa Bekalan di sebelah timur, Desa Ganjaran di sebelah selatan dan Desa Turen di sebelah barat. Desa yang terdiri atas 9 $\mathrm{RT}$ ini dapat dicapai melalui dua jurusan jalan raya dari kota Malang.

Keadaan topografi desa ini cukup baik karena sebagian besar merupakan dataran dan tanahnya terdiri dari jenis lotosol yang baik untuk persawahan, tegalan dan pertanian pada umumnya dengan produktivitas sedang sampai tinggi. Tingkat curah hujan rata-rata per tahun di sini antara 2000-3000 mm. Di samping itu desa ini dilewati sungai yang telah dimanfaatkan secara baik buat pengairan (teknis) terutama untuk tanaman tebu yang sebagian besar sudah sejak zaman Belanda diusahakan penduduk setempat maupun òleh penduduk desa-desa di beberapa kabupaten di sekitar kawasan ini.
Luas wilayah desa Putukrejo adalah sekitar 367 ha dengan rincian penggunaan tanah sebagai berikut :

\begin{tabular}{llc}
\hline No. & Penggunaan tanah & Luas \\
\hline 1 & Tanah pertanian \\
& (pengairan teknis) & 256,516 ha \\
2 & Tanah tegalan & 39,500 ha \\
3 & Tanah pekarangan & 62 ha \\
4 & Jalan/sungai & 4,004 ha \\
5 & Lain-lain & 4,980 ha \\
\hline
\end{tabular}

Berdasarkan data kependudukan per 25 September 1979, penduduk desa ini seluruhnya berjumlah 2870 jiwa terdiri atas 638 kepala keluarga. Dibanding dengan luas desa $\left(3,67 \mathrm{~km}^{2}\right)$, desa ini dapat diklasifikasi sebagai desa berpenduduk padat yaitu $\pm 802 \mathrm{jiwa} / \mathrm{km}^{2}$ dan rata-rata pertambáhannya \pm 50 jiwa/ tahun. Akan tetapi jika diperhitungkan jumlah rata-rata anak dalam tiap keluarga ternyata tidak melebihi dari 4 orang. Uraian penduduk jenis kelamin tercatat 1415 orang laki-laki dan 1455 orang perempuan.

Rincian penduduk berdasarkan kelompok umur tecermin dalam tabel berikut :

\begin{tabular}{cccc}
\hline Umur & \multicolumn{4}{c}{ Laki-laki Perempuan } & Jumlah \\
\hline $0-5$ tahun & 264 & 282 & 546 orang \\
$6-15$ tahun & 306 & 314 & 620 orang \\
$16-25$ tahun & 231 & 303 & 534 orang \\
$26-55$ tahun & 249 & 263 & 512 orang \\
$56-$ ke atas & 353 & 299 & 652 orang \\
\hline
\end{tabular}

Tabel di atas memperlihatkan bahwa kelompok usia muda merupakan jumlah terbesar penduduk desa. Dalam hubungan ini menurut perkiraan terdapat lebih kurang sebanyak $30 \%$ penduduk dapat dikategorikan sebagai 
tenaga non-produktif seperti anak-anak di bawah usia kerja dan orang-orang tua lanjut usia.

\section{Keadaan Sosial dan Ekonomi}

Desa Putukrejo yang merupakan tempat pemukiman dan tanah pertanian sebagimana dikenal sekarang, dahulu merupakan daerah atau areal perkebunan tebu, mulai zaman kolonial, untuk memenuhi keperluan pabrik gula yang letaknya tidak begitu jauh di luar desa Putukrejo. Sampai saat ini masih terdapat dan digunakan jalan lori yang melintas desa untuk pengangkutan tebu ke pabrik gula "Krebet Baru".

Jalan-jalan desa, walaupun belum diberi aspal tetapi cukup terpelihara, sudah dapat dilintasi kendaraan umum, begitu pula kondisi pengairannya sangat baik dan terawat karena disadari bahwa ia memegang peranan penting bagi pertanian masyarakat setempat.

Kebanyakan penduduknya adalah pendatang dari Madura yang pada umumnya sudah sejak lama dan turuntemurun menetap dan bermukim menjadi kelompok besar. Karena itu bahasa dialek Madura digunakan dalam percakapan sehari-hari di samping bahasa setempat.

Agama Islam yang dianut oleh seluruh penduduk sangat mendalam pengaruhnya terhadap perikehidupan masyarakatnya sehingga corak tradisi budaya yang dilatarbelakangi ajaran agama ini paling menonjol dirasakan dalam kegiatan kemasyarakatan mereka. Berkenaan dengan itu dalam usaha pembangunan desa ternyata para alimulama setempat mempunyai peranan yang penting sebagai pemimpin informal, dan dengan kerja sama yang serasi dengan pamong desa telah berhasil mendinamisasi masyarakatnya. dengan menanamkan pengertian dan melaksanakan ajaran-ajaran agama Islam melalui pengajian-pengajian yang diadakan secara rutin telah membuat pergaulan masyarakatnya dalam suasana tenang dan tenteram, sehingga dapat mencurahkan cukup perhatian kepada usaha pertanian sebagai mata pencaharian utama sebagian besar penduduknya.

Sebagaimana lazimnya di tiap-tiap desa, desa Putukrejo juga mempunyai sebuah balai desa di mana rapat-rapat desa diadakan dan juga sekaligus merupakan kantor Kepala Desa (Lurah). Letaknya yang strategis dikelilingi pemukiman dan pusat lalu-lintas umum menjadikan sekitar tempat tersebut sebagai pusat berbagai kegiatan sosial masyarakat desa ini, dan juga untuk keperluan pelayanan umum bagi petugas-petugas resmi yang sewaktu-waktu bertugas di desa ini. Pengurusan administrasi desa walaupun belum memadai hasilnya, mengingat keterbatasan tenaga pelaksana, secara bertahap dengan adanya sistem registrasi yang standar ditentukan oleh Pemerintah sangat membantu memudahkan pelaksana baik dalam pembuatan data, catatan keuangan dan laporan.

Di desa ini terdapat 3 buah masjid yang besar, 38 langgar dan beberapa fasilitas pendidikan yaitu 2 buah Taman Kanak-kanak, 1 gedung SD Inpres, 2 buah Madrasah Ibtidaiyah (SD), dan 2 buah Madrasah Tsanaqiyah (SLTP). Murid-murid yang belajar di seluruh tingkatan sekolah tersebut sebanyak 799 orang dengan jumlah guru 38 orang. 
Gambaran tingkat pendidikan penduduk desa adalah sebagai berikut :

\begin{tabular}{llr}
\hline No. & Keadaan Tingkat Pendidikan & Jumlah \\
\hline 1 & Tidak bersekolah/tidak tamat SD & 1429 orang \\
2 & Lulusan SD/Madrasah Ibtidaiyah & 1089 orang \\
3 & Lulusan SLTP/Madrasah Tsanawiyah & 16 orang \\
4 & Lulusan SLTA/sederajat & 6 orang \\
5 & Sedang belajar di Perguruan Tinggi & 2 orang \\
\hline
\end{tabular}

Kelihatannya pemuda desa maupun orang tua di sini belum banyak berorientasi kepada pendidikan umum, juga belum kepada pendidikan lebih tinggi. Umumnya golongan pemuda lebih senang tinggal di desanya melanjutkan pekerjaan bertani. Kecilnya animo memasuki sekolah membawa pengaruh lebih jauh terhadap kurangnya kecerdasan anak, masalah gizi, serta keterbelakangan. Di antara sebab-sebabnya adalah terbatasnya kemampuan pembiayaan, dipergunakannya tenaga anakanak sebagai modal pertanian di samping kurangnya kesadaran tentang pentingnya pendidikan umum dan pendidikan lebih tinggi.

Rumah-rumah berjumlah 391 rumah gedung, -36 rumah kayu dan 221 rumah bambu. Kebanyakan letak rumah saling berdekatan dan sudah makin teratur susunannya mengikuti jalur lalu-lintas desa.

Dalam tahun 1979 desa Putukrejo telah mendapat aliran listrik berkekuatan 4 KVA dalam rangka perluasan jaringan dari kabupaten. Untuk sementara daya listrik tersebut baru dapat dimanfaatkan bagi penerangan perumahan sebagian kecil penduduk.

Suatu kebutuhan yang mendesak bagi masyarakat desa dan sangat diharapkan adalah keperluan air minum, Karena .menyangkut pembiayaan yang cukup besar untuk pengalirannya dari sumber terdekat $( \pm 3 \mathrm{~km}$ ) di luar desa maka sampai sekarang belum dapat direalisasi pembangunannya.

Bertani merupakan mata pencaharian utama sebagian besar penduduk desa Putukrejo yang dirasakan tidak saja sebagai kejadian alamiah, tetapi juga merupakan proses sosial dan ekonomi yang tidak jarang bersangkut-paut dengan masalah adat dan kepercayaan.

Data setempat memperlihatkan struktúr pekerjaan penduduk sebagai berikut :

\begin{tabular}{|c|c|c|c|}
\hline No. & Pekerjaan & Jumlah & Prosentase \\
\hline 1 & Petani & 726 orang & $94,01 \%$ \\
\hline 2 & Buruh tani & 747 orang & \\
\hline 3 & Pedagang & 93 orang & $5,05 \%$ \\
\hline 4 & Pegawai/ABRI & 5 orang & \\
\hline 5 & Pengrajin/industri & 21 orang & $0,94 \%$ \\
\hline
\end{tabular}

Pemilikan tanah secara global dapat dibagi ke dalam dua kategori, yaitu tanah milik desa seluas 14,680 ha yang diperuntukkan sebagai tanah bengkok untuk keperluan Pamong Desa $( \pm 10$ orang) dan tanah penduduk seluas 347,616 ha. Apabila diambil luas efektif tanah pertanian di seluruh desa ini, yaitu seluas $\pm 359,416$ ha yang terdiri dari :

\begin{tabular}{|c|c|c|}
\hline No. & Jenis tanah & Luas \\
\hline 1 & tanah pertanian (irigasi teknis) & $256,616 \mathrm{he}$ \\
\hline 2 & ladang & 39,5 he \\
\hline 3 & pekarangan & 62 \\
\hline 4 & lain-lain & $1,4 \mathrm{ha}$ \\
\hline
\end{tabular}

Maka dengan jumlah petani sebanyak 1.472 orang, gambaran penguasaan tanah pertanian rata-rata bagi penduduk yang hidupnya tergantung dari per- 
tanian hanyalah seiuas 0,244 ha. Jenis tanaman yang pada umumnya diusahakan dalam pertanian penduduk adalah tebu seluas 180 ha, padi seluas 110 ha dan jagung seluas 50 ha, di samping itu ditanam pula palawija, sayuran, buahbuahan. Kelapa biasanya ditanam sebagai tanaman pekarangan oleh penduduk. Dalam keadaan harga hasil pertanian yang menguntungkan para petani, baik yang tanahnya merupakan areal tradisional tebu maupun petani pangan, mereka bebas mengatur pola rotasi tanaman sesuai dengan musim. Diperoleh keterangan bahwa karena padi memerlukan pengairan yang lebih lama dibandingkan dengan tebu, maka ternyata air irigasi yang ada tidak akan mencukupi apabila seluruh areal yang beririgasi ini ditanami padi. Petani di desa ini sudah mengenal cara bertani yang lebih produktif terutama sejak dilansirnya program intensifikasi pertanian oleh pemerintah melalui BIMAS/ INMAS.

Walaupun desa Putukrejo belum merupakan daerah yang diwajibkan memproduksi padi dalam program pengadaan pangan nasional, tetapi pengertian dan permintaan terhadap saprodi (sarana produksi) cukup besar. Hanya saja di sana-sini masih terlihat adanya kebutuhan yang mendesak dari kalangan penduduk petani subsisten menyebabkan kurang lancarnya pengembalian kredit yang diberikan oleh Pemerintah bagi petani-petani kecil. Kenyataan ini merupakan indikasi lebih jauh tentang situasi kehidupan golongan petani tersebut dan terlebih lagi bagi buruh tani yang cukup banyak jumlahnya. Mereka itu tidak bisa mencapai aneka bantuan pemerintah dalam pro- gram pertanian ini karena tidak mempunyai tanah. Keadaan golongan ini dalam situasi paceklik memerlukan perhatian dan bantuan untuk mempertahankan kehidupan mereka.

Pada umumnya di daerah Malang Selatan, khususnya Kecamatan Gondanglegi, tanaman tebu merupakan usaha tani yang menguntungkan rakyat setempat untuk langsung dijual ke pabrik gula. Telah sejak lama di daerah ini terdapat suatu koperasi yang cukup kuat kedudukannya dan mempunyai cabang di berbagai desa yang berperan pula melindungi petani tebu dalam berhubungan dengan pihak pabrik gula yaitu "Koperasi PETERMAS" (Pertanian Tebu Rakyat Malang Selatan). Belakangan ini, walaupun masih tetap beroperasi dengan baik, peranan koperasi ini tidak sebagaimana beberapa waktu yang lalu, terutama dengan berkembangnya sistem KUD dan adanya perubahan kebijaksanaan dalam hal pertanaman tebu dan hubungannya dengan pabrik. Karena perekonomian Desa Putukrejo desa Putukrejo sedikit banyak bergantung pada tanaman tebu, maka gambaran yang diperoleh dari hasil wawancara dengan berbagai pihak menunjukkan bahwa petani penanam tebu di desa ini biasanya menghadapi problem hubungan dengan pabrik gula, ijon dan pengairan.

Sebagaimana diketahui sistem bagihasil dalam bentuk gula yang berlaku antara pabrik dengan petani tebu adalah $60: 40 ; 60 \%$ dari gula yang dihasilkan merupakan bagian pabrik dan $40 \%$ untuk petani. Sistem bagi-hasil yang didasarkan atas instruksi Menteri Pertanian tahun $1979 \mathrm{itu}$, menurut sementara petani dianggap masih kurang mengun- 
tungkan karena pihak pabrik telah menetapkan dajlam kontrak jual-beli tebu rakyat ini semacam biaya pengangkutan yang tinggi. Di samping itu terdengar pula keluh-kesah petani kepada pabrik sehubungan dengan penetapan rendemen, waktu penebangan dan proses taksasi oleh pabrik yang berakibat memperlambat diterimanya pembayaran kepada petani (biasanya dalam bentuk D.O. yang bisa diperjualbelikan). Keadaàn inilah yang menyebabkan sering terjadinya praktek ijon yang sangat merugikan petani. Pihak koperasi ternyata tidak berdaya mengatasi ijon ini karena terbatasnya permodalan/plafond kredit yang dibolehkan, sedangkan pihak pabrik tidak pula dapat memberi uang muka kepada petani tebu.

Meluasnya penanaman tebu di luar kecamatan. Gondanglegi dan Bululawang yang merupakan areal tradisional pabrik gula "Krebet Baru", telah mempersulit kedudukan petani tebu di sini, karena ternyata banyak hasil tebu dari luar kawasan itu rendah mutunya. Harganya yang rendah telah mempengaruhi tingkat harga yang berlaku. Hal ini menempatkan pihak pabrik dalam posisi bargaining yang kuat terhadap petani.

Walaupun demikian secara rata-rata tingkat kemakmuran rakyat petani penanam tebu di desa ini antara lain menilik keadaan perumahan serta halaman sekitarnya, dapat dikatakan tidak kurang daripada tingkat kemakmuran rakyat tani umumnya di Jawa Timur. Salah-satu indikator terlihat adanya pemilikan sejumlah barangbarang termasuk kategori lumayan di antara penduduk, yaitu mobil sebanyak
7 buah, sepeda motor 47 buah, sepeda 170 buah, televisi 18 buah, dan radio 41 buah, walaupun ini hanya terbatas seki$\operatorname{tar} 3-5 \%$ golongan penduduk desa yang mempunyainya.

Gambaran perhitungan sementara mengenai usaha tani tebu berdasarkan keterangan yang dapat dikumpulkan antara lain dari petugas koperasi "Petermas" adalah sebagai berikut :

a. Apabila 1 ha sawah rata-rata menghasilkan $800 \mathrm{kw}$ tebu, setelah dihitung menurut ketentuan bagi hasil yang berlaku, maka petani tebu akan menerima sekitar $42 \mathrm{kw}$. gula a' Rp. $19.400,00=$ Rp. $814,800,00$ (brutto).

b. Biaya yang dikeluarkan petani per $\mathrm{kw}$ tebu menurut pihak koperasi "Petermas" adalah :

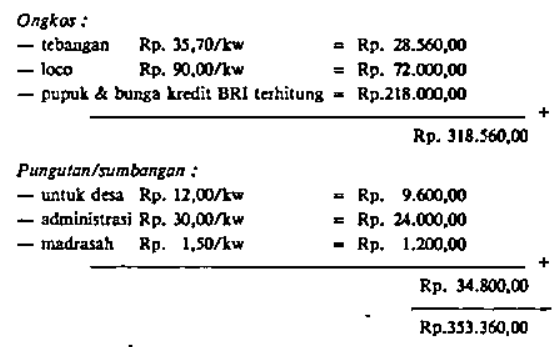

Dari perhitungan tersebut di atas petani tebu akan menerima brutto sebesar. Rp. $814.800,00-R$ p. $353.360,00=$ Rp. $461.440,00$ ditambah pengembalian oleh pabrik kepada petani berupa substitusi tetes dinilai Rp. 48,75 per $\mathrm{kw}$.

Sungguhpun demikian dari jumlah tersebut masih terdapat pengurangan untuk :

- ongkos tambahan a' Rp. 4,00 per kw.

- ongkos pengawalan Rp. 30,00 per lori

- harga karung a' Rp.575,00 per karung

- cukai/pajak penjualan sekitar $15 \%$

- Ipeda ( \pm Rp.i5.800,00/ha.) 
Konsumsi pupuk per ha berdasarkan catatan kredit BRI adalah sebanyak 800 $\mathrm{kg}$, biasanya petani masih kekurangan dan berusaha membeli sendiri di pasaran bebas.

Demikianlah sedikit gambaran mengenai usaha tani tebu yang sebagian besar penduduk desa Putukrejo menggantungkan kehidupan ekonominya kepada usaha tersebut.

Dari segi lain, usaha yang juga kelihatannya mulai digalakkan oleh sebagian penduduk yang mampu ialah usaha peternakan. Menurut data setempat terdapat beberapa jenis ternak yang ada di desa ini, yaitu :

\begin{tabular}{llr}
\hline No. & Jenis ternak & Jumlah \\
\hline 1 & sapi & 122 ekor \\
2 & kuda & 8 ekor \\
3 & kambing & 125 ekor \\
4 & angsa & 11 ekor \\
5 & itik & 130 ekor \\
6 & ayam & 1500 ekor
\end{tabular}

Data tersebut menunjukkan bahwa menilik jumlah dan jenisnya, pemeliharaan ternak di sini masih pada tingkat untuk memenuhi kebutuhan sendiri. Untuk ternak gembalaan agak sulit dikembangkan karena tidak terdapatnya padang rumput. Demikian pula halnya dengan usaha kerajinan/industri rakyat mengingat keterbatasan dalam berbagai hal terutama anyaman bambu/rumput secara sangat terbatas produksinya dan pembuatan batu-bata untuk bangunan.

Irigasi yang merupakan prasarana vital bagi pertanian desa ini terdiri dari 2 buah waduk, 2 saluran induk sepanjang $465 \mathrm{~m}$ dan 14 buah dam dan verdeelwerk(pembagi). Pada umumnya dalam keadaan baik, hanya beberapa bagian memerlukan rehabilitasi mengingat usia bangunannya sudah cukup tua. Berhubung pentingnya ketertiban dalam penggunaan air irigasi ini, penyuluhan dan bimbingan kepada petani melalui organisasi Kontak Tani selalu diberikan dan karena itu penggunaan air berada langsung di bawah pengaturan desa, yang untuk setiap hektar areal pengairan ditarik pungutan sebesar Rp. $1.000,00$ oleh pemerintah desa.

Desa Putukrejo dibatasi di sebelah timurnya jalan kabupaten yang menampung arus lalu-lintas angkutan umum cukup padat, menghubungkan MalangGondanglegi, terutama merupakan jalur angkutan tebu ke pabrik gula "Krebet Baru". Sekarang ini (pada waktu penelitian dilakukan) keadaan jalan tersebut rusak, meskipun begitu arus kendaraan yang melewati tidak berkurang, karena merupakan jalan ekonomi. Di samping jalan rel untuk lori yang melintasi desa, terdapat jalan desa utama selebar $2,5 \mathrm{~m}$ yang sudah dapat dilalui kendaraan pengangkut kecil. Letak jalan ini memanjang melintasi bagian utara dan tengah desa dan sudah dikeraskan dengan batu, tetapi masih belum dibubuhi aspal. Juga jalan-jalan cabang ke perkampungan penduduk masih berupa jalan tanah dan untuk membuka hubungan ke luar desa terdapat dua buah jembatan besi dan dua buah jembatan beton.

Mungkin karena hubungan yang dekat dengan ibukota kabupaten dan pertimbangan kebutuhan harian penduduk tidak begitu banyak, maka di desa ini tidak terdapat pasar; yang ada hanya beberapa kios dan warung kecil yang menjual kebutuhan sehari-hari seba- 
nyak 11 buah tersebar di wilayah desa. Untuk menampung hasil pertaniannya telah didirikan sebuah lumbung desa dengan kapasitas besar di samping sebuah gudang yang memang dirasakan keperluannya oleh para petani.

Perkiraan hasil-hasil utama yang dikeluarkan dari desa ini, berupa produk pertanian, adalah :

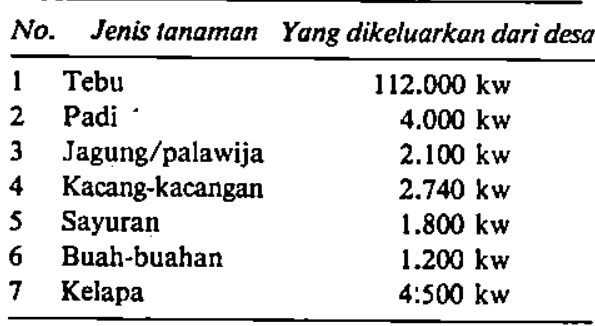

Berdasarkan kegiatan ekonomi dan pembangunannya, desa Putukrejo telah diklașifikasikan menurut tingkat perkembangan desa sebagai suatu desa swakarya, yaitu suatu desa dengan tingkat output antara Rp.100 s.d.200 juta pertahun. Kategori ini menunjukkan bahwa rata-rata income perkapita penduduk berkisar antara Rp. 30.000,00 sampai Rp. $60.000,00$ per tahun atau dengan perhitungan mata uang dolar Amerika Serikat sekarang (1974) sebesar US\$ $50.00-\$ 100.00$ perkapita/tahun.

Kesehatan, Keluarga Berencana dan Kebudayaan

Kesehatan dan Keluarga Berencana dilola oleh Pusat Kesehatan Masyarakat .(Puskesmas) Kecamatan Gondanglegi, Kabupaten Malang, dan dipimpin oleh dokter Eli Wijaya yang dibantu oleh 2 orang tenaga paramedis (mantri kesehatan) dan 2 orang tenaga administrasi. Khusus di desa Puturejo, pelayanan kesehatan selain diberikan oleh mantri kesehatan.yang bertugas keliling sebulan sekali, juga diberikan oleh 2 orang dukun bayi berijazah, seorang dukun pijat dan 4 orang dukun tradisional. Penyakit yang merata di kalangan penduduk adalah malaria, yang penanggulangannya ditangani oleh Puskesmas Gondanglegi dengan mengadakan suntikan keliling dan pengobatan secara cuma-cuma. Keadaan kesehatan pada umumnya masih rendah; hambatan utamanya adalah air minum penduduk yang kurang bersih dan kurang memadai persyaratan kesehatan. Air yang digunakan penduduk sebagian besar berasal dari air irigasi pertanian dan mata air yang terdapat di luar desa Putukrejo. Sumur tidak digunakan, karena sampai kedalaman 38 meter air belum dapat keluar.

Dalam bidang keluarga berencana, tercatat jumlah peserta sebanyak 433 orang. Dari jumlah tersebut tercatat 70 orang menggunkan IUD, kondom 34 orang dan pil sebanyak 309 orang. Sedikitnya IUD dan kondom digunakan peserta disebabkan alasan agama, dan adanya akibat smping dari penggunaan kedua macam cara tersebut. Meskipun demikian, program keluarga berencana dapat dikatakan baik berdasarkan ratarata jumlah anak di desa Putukrejo di bawah 5 orang anak.

Adapun tentang kegiatan kebudayaan, perlu dijelaskan bahwa pengertian kebudayan di sini dibatasi pada pengertian kesenian dan olah raga yang sebagian besar dilakukan pemuda-pemudi untuk mengisi waktu luangnya. Bentuk kesenian yang berkembang adalah kesenian yang mendapat pengaruh dari penghayatan mereka terhadap agama Islam yang dipeluknya. Sedang kesenian yang dipengaruhi atau bersumber dari 
kebudayan suku bangsanya (dalam hal ini suku Madura yang merupakan. $99 \%$ penduduk Putukrejo ) tidak terlihat kehadiran dan perkembangannya. Bentuk kesenian yang dipengaruhi oleh penghayatan mereka terhadap agama Islam yang dipeluknya adalah:

a. Diba'an, yang dilakukan oleh 2 kelompok pemuda dan 2 kelompok pemudi setiap malam Kamis dan Jumat.

b. Manakiban atau pembacaan manakib Syeikh Abdul Kadir Jaelani dilakukan oleh 1 kelompok pemuda/ orang tua sebulan seklai.

Kegiatan olah raga yang ada meliputi sepak-bola 1 club, volley 2 club, bulutangkis 3 club, dan tenis meja 1 club.

Kegiatan sosial lainnya yang dikoordinasi oleh LSD (Lembaga Sosial Desa) terdiri dari:

a. PKK (Pembina Kesejahteraan Keluarga) kegiataannya meliputi :

1) Kursus ketrampilan sebulan sekali dengan peserta sebanyak 16 orang.

2) Pertemuan periodik sebulan sekali dengan peserta sebanyak 27 orang.

3) Arisan sebulan dua kali dengan - peserta sebanyak 41 orang.

4) Kursus kader gizi sebulan dua kali dengan peserta sebanyak 31 orang.

5) Penataran kader.

6) Kursus 10 segi pokok PKK.

7) Dakwah sebulan 9 kali.

8) Olah raga dan kesenian yang dikhususkan bagi ibu-ibu dan pemuda-pemudi (tidak tetap diadakan).

b. Pramuka terdapat 2 gugus depan. c. Kelompok Pendengar 2 buah (tidak aktif).

d. Kontak tani 2 buah.

e. Hansip yang bertugas menjaga keamanan dan ketertiban desa sebanyak 1 peleton.

\section{Kehidupan Agama}

Berdasarkan catatan yang terdapat di kantor desa Putukrejo dan kantor kecamatan Gondanglegi, agama Islam adalah satu-satunya agama yang ada di desa Putukrejo dan dipeluk oleh seluruh penduduk. Tidak diketahui secara pasti kapan agama Islam masuk ke desa tersebut. Berdasarkan keterangan Kiyai Haji Nurhamid, salah seorang ulama di desa Putukrejo, perkembangan Islam di desa tersebut dimulai sekitar tahun 1936 yang ditandai dengan berdirinya 2 buah pesantren di desa sebelah utara dengan pengasuh Kiyai Haji Syamsul Arifin dan sebelah selatan dengan pengasuh Kiyai Haji Asy'ari, ke dua-duanya dari Madura. Pada waktu itu perbuatan maksiat seperti perjudian, tayuban dan perzinaan banyak dilakukan oleh penduduk desa. Masuknya Jepang ke Indonesia sekitar tahun 1942 membawa pula perubahan masyarakat desa, terutama dengan berkurangnya perbuatan maksiat karena alasan-alasan ekonomi dan keamanan.

Sekitar tahun 1945-1948 penduduk desa Putukrejo menggabungkan dirinya dalam Jamiat Nahdatul Ulama dan menyalurkan aspirasi politiknya lewat partai politik Masyumi. Dalam periode ini pemuda-pemuda desa bergabung dalam laskar Hizbullah ikut berjuang mempertahankan kemerdekaan Indonesia bersama-sama dengan tentara dan laskar perjuangan lainnya. Dalam suasana peperangan itu pula diusahakan 
berdirinya madrasah sebagai sarana pendidikan agama Islam yang diberi nama Madrasah Al-Khairiyah dan Madrasah Nurul Irsyad.

Setelah periode tersebut, Islam terus menampakkan kehadiran dan pengaruhnya, sehingga sampai dewasa ini agama selain Islam tidak pernah ada dan hidup berkembang di desa tersebut. Dalam seluruh bidang sosial dan budaya yang terdapat di desa tersebut, pengaruh agama Islam adalah yang paling menonjol. Begitu pula organisasi Nahdatul Ulama baik ketika menjadi organisasi sosial, maupun organisasi politik, tetap merupakan organisasi yang terkuat serta berpengaruh di desa tersebut baru terjadi sekitar tahun 1970-an, yaitu, Golkar, yang kelihatannya tidak mampu berkembang dengan pesat. Selain Nahdatul Ulama dan Golkar, ormas lainnya belum pernah masuk ke desa tersebut.

Dewasa ini keadaan kehidupan ummat beragama di Putukrejo dapat diterangkan sebagai berikut:

\section{Ajaran Agama dan Pemeluknya}

Penduduk Putukrejo yang seluruhnya beragama Islam mengaku penganut Ahlus sunnah wal jamaah, yang dalam masalah hukum mengikuti mazhab Syafi'i.

Di kalangan kaum awamnya, pengaku sebagai penganut Ahlus sunnah wal jamaah dan pengikut mazhab Syafi'i tidak dipahami secara mendalam, tetapi di kalangan ulamanya kelihatan usaha untuk secara konsekuen memahami dengan sadar dan semaksimal mungkin mengikutinya. Ada kecenderungan bagi ulama-ulama di desa tersebut menggunakan ijtihad untuk memberikan tafsiran-tafsiran baru, terutama dalam bidang hukum, untuk melayani perubahan dan perkembangan masyarakat.

Secara struktural, pemeluk Islam di desa Putukrejo dapat dibagi menjadi dua kelompok, yaitu kaum awam dan ulama. Kaum awam adalah mereka yang memahami ajaran Islam secara mendalam dan tidak memilih profesinya sebagai ahli agama. Akan tetapi dalam penghayatan dan pengamalan agama ada yang berusaha secara mendalam, di samping ada yang menghayati dan mengamalkan secara kurang mendalam. Dalam kelompok kaum awam, yang merupakan kelompok terbesar, golongan yang berusaha menghayati dan mengamalkan ajaran Islam secara mendalam, merupakan golongan yang terbesar terdapat di desa itu. Hal ini disebabkan karena usaha pendidikan agama secara merata dan terpadu yang dilakukan oleh para ulama dan pemimpin desa tersebut. Kaum ulama, yakni mereka yang secara sadar memilih profesi ahli agama sebagai salah-satu pilihan hidupnya dan mendapat pengakuan dan penghargaan masyarakat sebagai ulama dan mendapatkan panggilan atau gelar kiyai. Terhadap pengakuan, penghargaan dan gelar ini, mereka menerimanya dan berusaha menyesuaikan diri dengannya, dalam sikap, tindakan, pembicaraan, bahkan cara berpakaian.

Di kalangan pemeluk Islam di Putukrejo, terdapat 9 orang yang dianggap oleh masyarakat setempat sebagai ulama. Anggapan ini didasarkan pengakuan bahwa dalam bidang agama mereka lahir dari kalangan ulama, baik di desa tersebut maupun di tempat lain, juga memperkuat anggapan masyarakat akan keulamaan mereka yang telah diwariskan dan dikembangsuburkan. 
Satu hal penting perlu dicatat bahwa antara ulama yang berada di desa atas ikatan darah, maupun ikatan perkawinan di antara keturunan mereka. Bahkan mereka kelihatan berusaha memperkuat ikatan-ikatan tersebut dalam proses berkeluarga di antara anak dan keluarga mereka.

Para ulama tersebut sebagian besar mendapatkan pendidikan dan pengetahuan agamanya di pesantren-pesantren Jawa Timur, Madura dan Jawa Tengah. Seorang di antaranya selain mendapatkan pendidikan dan pengetahuan agamanya di Pesantren, juga mendapatkannya di IAIN Sunan Ampel Surabaya. Secara khusus tidak seorang pun di antara mereka mendapatkan pendidikan umum di sekolah umum. Pengetahuan umum yang mereka miliki diperoleh dari pesantren dan daiam proses belajar dan pengalaman selanjutnya. Meskipun demikian, seorang di antaranya diakui penduduk sebagai ahli pertanian, karena berani melakukan percobaan-percobaan dibidang pertanian yang dinilai pendduk sangat berhasil. Keadaan ekonomi para ulama rata-rata cukup, seorang di antaranya kurang mampu dan seorang lainnya mempunyai basis ekonomi yang kuat, bahkan dianggap sebagai orang terkaya di kampung tersebut. Di samping mengajarkan agama, di antara para ulama itu terdapat petani, pedagang, pejabat desa dan pengurus koperasi "Petermas" di Kecamatan Gondanglegi.

Dalam masyarakat desa, pengaruh mereka sangat kuat sebagai piminan informal dan mereka melakukan peranannya bukan hanya sebagai pemimpin agama, tetapi juga sebagai pemimpin masyarakat yang pengaruhnya justrù melebihi pengaruh-pengaruh pimpinan desa. Kesan kuatnya pengaruh ulamaulama tersebut disadari dan diakui sendiri oleh Kepala Desa, sehingga dalam banyak hal Kepala Desa selalu mengikutsertakan mereka dalam menangani masalah-masalah pemerintah desa. Satu contoh kecil yang menunjukkan kuatnya pengaruh agama dan ulama setempat, adalah diliburkannya atau ditutupnya kantor desa pada hari Jumat selain hari Ahad, atas saran dari ulama setempat. Dalam masalah-masalah desa yang lebih besar, kebijaksanaan pemerintah desa yang bagaimanapun, tidak akan didengar dan diterima penduduk desa bila belum mendapat persetujuan dari ulama setempat.

\section{Organisasi Massa}

Seperti yang telah disinggung di atas, organisasi massa yang ada di desa tersebut adalah Nahdlatul Ulama. Tetapi di samping itu terdapat pula organisasi yang bersifat keagamaan yang tidak bertentangan dengan dasar-dasar organisasi Nahdlatul Ulama, yaitu MUUAD dan Tharikat Nagsyabandiyah. Nahdlatul Ulama yang secara historis telah berakar di desa tersebut, dewasa ini kurang menampakkan pengaruhnya secara nyata, lebih-lebih setelah organisasi ini bergabung dalam wadah Partai Persatuan Pembangunan. Pengaruh yang masih nampak adalah di bidang pendidikan dan pengajaran.

Bidang pendidikan dan pengajaran ini dilayani oleh 2 buah sekolah Taman Kanak-kanak, 2 buah Madrasah Ibtidaiyah dan 2 buah Madrasah Tsnawiyah, dengan murid seluruhnya berjumlah 625 orang anak serta diasuh oleh 38 orang guru. Madrasah-madrasah itu mengkhususkan diri dalam pendidikan 
- agama, tanpa melengkapinya dengan ilmu pengetahuan umum lainnya. Barubaru ini, oleh Kepala Desa telah direncanakan perubahan sistem yang ada dengan sistem pendidikan di Tsanawiyah Negeri, dengan tujuan agar lulusanlulusan madrasah tersebut di samping memahami bidang agama, juga memahami ilmu pengetahuan umum lainnya.

Selain dalam bidang pendidikan, kegiatan organisasi Nahdlatul Ulama tidak nampak, meskipun penduduk desa masih mengakui dirinya sebagai keluarga besar Nahdlatul Ulama. Bahkan nampak kecenderungan ulama-ulama setempat untuk lebih mementingkan pemecahan masalah-masalah desa dibanding keterikatan mereka terhadap Nahdlatul Ulama, baik dalam penetapan masalah-masalah hukum Islam, sosial maupun politik.

Tharikat Naqsyabandiyah yang berada di desa tersebut terbagi menjadi 2 kelompok, yang masing-masing dipimpin oleh Kiyai Haji Abu Abbas dan Kiyai Haji Ahmad Qasim. Tharikat Naqsyabandiyah bertujuan untuk lebih mendekatkan diri kepada Allah dengan jalan memperbanyak wirid, zikir, doadoa, serta amalan-amalan lainnya yang bersifat batiniah. Pendukung-pendukungnya sebagian besar orang-orang tua dan sudah sedikit kecenderungannya pada masalah-masalah dunia. Sekarang ini kegiatannya dilakukan setiap malam Selasa dengan tempat bergiliran. Dibandingkan dengan tahun 1960-an, perkembangan Tharikat Nagsyabandiyah sangat berkurang, yang antara lain disebabkan oleh terjadinya konflikkonflik dengan ummat Islam lainnya yang lebih mementingkan syari'at dan masalah-masalah yang bersifat lahiriah.
Selain itu kecenderungan penduduk desa untuk sedapat mungkin memenuhi kebutuhan primer mereka seperti pangan, sandang dan papan menjadikan tharikat ini kurang populer di kalangan penduduk desa Putukrejo.

Organisasi keagamaan lainnya yang terdapat di desa Putukrejo adalah organisasi MUUAD kependekan dari "Musyawaah Ulama, Umara, Aghniya Desa" yang didirikan pada tahun 1976. Sepanjang pengetahuan saya organisasi seperti MUUAD ini hanya terdapat di desa Putukrejo, yang pimpinannya terdiri dari tiga lapisan masyarakat yang paling berperan di desa, yakni Ulama, Umara (pimpinan formal desa) dan Aghniya, yakni orang-orang kaya di desa. Semula MUUAD adalah organisasi yang didirikan untuk mengelola pelaksanaàn zakat saja. Akan tetapi dalam perkembangannya tidak hanya bergerak di bidang zakat semata, tetapi menjangkau masalah-masalah sosial lainnya yang timbul di desa tersebut. Dalam struktur pemerintahan desa, MUUAD merupakan organisasi nonformal desa yang melakukan peranan menentukan dalam Pemerintahan desa. Peranan itu dapat dilihat dengan diterimanya keputusan-keputusan MUUAD oleh Rembug Desa/LSD yang kemudian dijadikan sebagai kebijaksanaan pemerintahan desa.

Untuk melaksanakan kegiatan MUUAD di bidang pengelolaan zakat, dibentuklah Badan Amil Zakat berdasarkan Surat Keputusan Bupati/Kepala Daerah Tingkat II Malang nomor D/215/K-73 4-10-1973, tentang pembentukan Badan Amil Zakat Kabupaten Malang. Selanjutnya jalinan kerja antara MUUAD dan Pemerintah Desa dapat 
digambarkañ dalam skema di bawah ini :

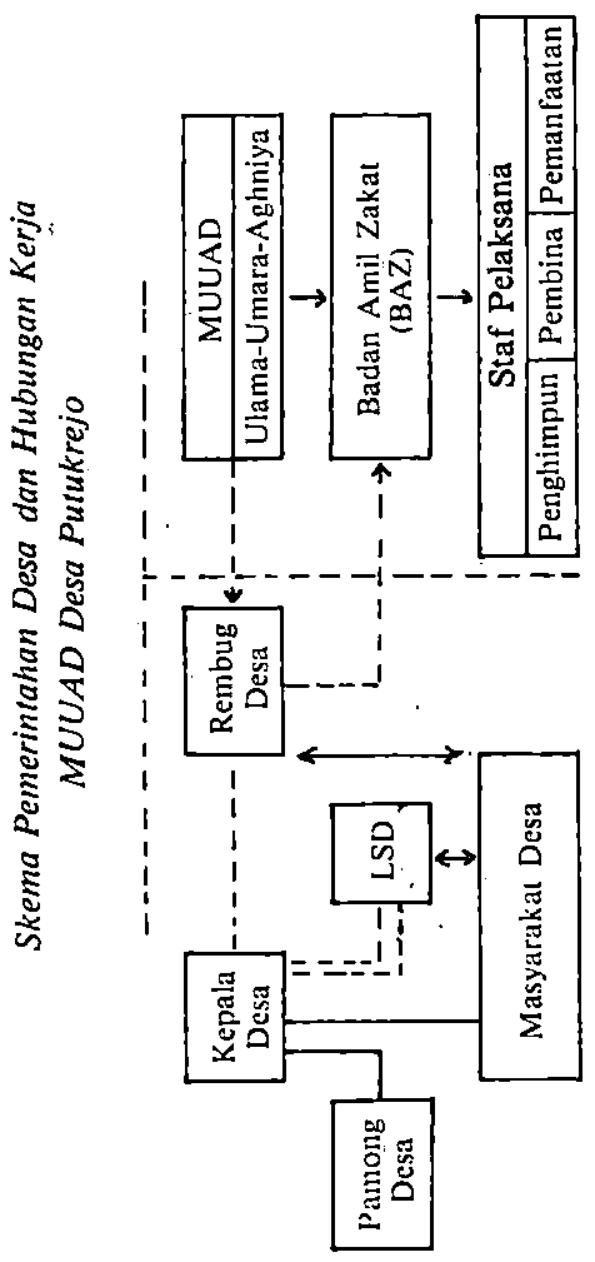

Penduduk desa Putukrejo melakukan kegiatañ agamanya secara pribadi di rumahnya masing-masing dan kegiatan kelompok yang biasanya dilakukan di . masjid-masjid, surau-surau, rumahrumah pribadi dan balai desa Putukrejo. Kegiatan-kegiatan itu antara lain:

1. Majelis Ta'lim yang dilakukan sebulan sekali di 6 tempat, seperti balai desa, masjid dan surau. Guru dari ulama setempat atau kadang-kadang diambil dari luar desa/daerah. Materi yang diberikan adalah agama secara umum dengan menggunakan metode ceramah. Pengikutnya campuran antara laki-laki dan perempuan, o;rang tua, anak-anak dan orang desa.

2. Pengajian rutin setiap hari Jumat sore di masjid, malam Sabtu dan malam Senin di langgar-langgar. Guru diambilkan dari ulama setempat, pengikutnya orang-orang tua laki-laki, materi diambilkan antara lain dari kitab-kitab Bidayah Hidayah, Sullamut Taufiq dan Safinatun Najat.

3. Kuliah Subuh setiap Jumat pagi di masjid Jami' dan masjid Babut Taufiq oleh ulama setempat.

4. Jamaah Khataman al-Quran sebanyak 4 kelompok pada setiap malam Kamis dan Jumat.

5. Jamaah Tahlil sebanyak 8 kelompok secara bergiliran tempatnya setiap malam Senin, Selasa dan Rabu.

Untuk melaksanakan kegiatan-kegiatan keagamaan tersebut tersedia 3 buah masjid yang cukup besar yang dilengkapi dengan alat penerangan listrik, pengeras suara, kolam tempat berwudhu yang memenuhi persyaratan kesehatan. Di samping itu tersedia pula 38 langgar pada setiap RT, baik milik pribadi-maupun yang sudah diwakafkan, serta dua buah pondok pesantren.

\section{Hubungan Antara Warga}

Pada umumnya hubungan intern ummat berjalan dengan baik, meskipun pada saat-saat tertentu kadang-kadang timbul konflik yang menimbulkan ketegangan, namun sejauh itu konflik secara 
fisik belum pernah terjadi di desa Putukrejo.

Di antara faktor-faktor yang memperkuat hubungan intern umat Islam Putukrejo ialah :

1. Kesamaan suku bangsa, yakni sebagian besar mereka berasal atau setidaktidaknya mempunyai hubungan darah dengan suku Madura.

2. Kesamaan orientasi agama, yakni Ahlussunnah Wal Jamaah, mazhab Syafi'i dalam hukum Islam dan $\mathrm{Nah}-$ dlatul Ulama dalam organisasi sosial dan politik.

3. Kesamaan mata pencaharian, yakni bertani atau berdagang.

4. Kesamaan pendidikan yaitu pendidikan agama menurut pola pesantren.

5. Selain itu, faktor lingkungan dan kewajiban serta ketaatan kepada kiyai serta pimpinan desa, yang juga berperan sebagai kiyai, dan pejabat pemerintah, ikut pula memperkuat hubungan di antara mereka.

Dalam hal ini perlu juga diteliti lebih lanjut dugaan bahwa suku Madura mempunyai kecenderungan taat kepada kiyai dan kepada pejabat pemerintah. Dalam menghadapi berbagai persoalan, baik yang murni agama maupun bukan, seperti masalah perkawinan, perdagangan dan sebagainya mereka meminta petunjuk kiyai. Dan apabila terjadi ada orang Madura melakukan pelanggaran, maka ia tidak melarikan diri, tetapi menyerahkan diri kepada polisi dengan mengakui kesalahannya dan bersedia menerima hukuman akibat dari perbuatannya itu.

Sedangkan konflik yang pernah terjadi biasanya akibat situasi yang datang dari luar lingkungan desa Putukrejo.
Faktor-faktor yang menyebabkan konflik antara lain masalah politik dan penafsiran agama yang berbeda. Peristiwa yang hampir saja menimbulkan konflik fisik terjadi pada tahun 1971 dan 1977 ketika Golkar ingin menarik sebagian penduduk yang mayoritas pendukung Partai Persatuan Pembangunan dalam pemilihan umum yang pertama dan kedua. Tindakan Golkar tersebut pada tahun 1971 sempat menimbulkan ketegangan terutama dengan pemudapemuda $A n s o r$ setempat yang dipimpin oleh Kiyai Haji Junaidi. Akan tetapi pada pemilihan umum 1977 pertentangan itu tidak sangat terasa karena sejak tahun 1974 Kiyai Haji Junaidi yang semula tokoh Ansor diangkat menjadi carik desa, dan masuk Golkar. Selain masuknya beberapa tokoh agama dalam Golkar anggapan masyarakat setempat bahwa pemilihan umum adalah urusan pemerintah dan kerukunan adalah urusan penduduk merupakan faktor-faktor yang mempersempit konflik di antara mereka.

Sedang konflik yang diakibatkan perbedaan penafsiran agama tersebut terjadi ketika pengikut Tharikat Naqsyabandiyah menganggap pemeluk Islam yang tidak masuk Tharikat Naqsyabandiyah kurang sempurna imannya. Anggapan ini sempat menimbulkan kemarahan pemeluk Islam lainnya, terutama ulama-ulama yang mementingkan syari'at dalam peribadatannya. Namun akhirnya masalah ini dapat teratasi, ketika kedua belah pihak telah bertemu dan bermusyawarah. Apalagi jika diingat bahwa tokoh-tokoh agama, baik yang masuk Tharikat maupun yang tidak, masih ada hubungan kekeluargaan. Perlu dijelaskan bahwa Kiyai Qasim 
yang memimpin Tharikat adalah menantu Kepala Desa Putukrejo.

\section{Zakat dan Pembangunan}

Masyarakat Indonesia kini berada dalam gemuruhnya pembangunan, tidak terkecuali desa Putukrejo. Lalu timbul pertanyaan bagaimana cara membangun desa itu, dari mana dananya siapa penggeraknya dan motivasimotivasi apa yang harus dipilih. Masyarakat desa Putukrejo, menurut pendapat pimpinan desanya, sekitar tahun 1970-an berada dalam keadaan statis dalam seluruh bidang kehidupan baik spiritual maupun material, dan sudah semestinya harus dibangunkan ke arah pembangunan spiritual dan material, batiniah dan lahiriah.

Cara yang ditempuh adalah yang tidak mengagetkan penduduk desa, dan untuk itu dicari cara yang berakar pada kehidupan sosial dan budaya setempat, dengan mengikutsertakan seluruh lapisan masyarakat yang ada dalam proses yang sedang berjalan. Karena terbatasnya anggaran desa, pilihan satu-satunya jatuh pada zakat sebagai sumber dana pembangunan desa.

\section{Ajaran Zakat dalam Islam}

Zakat dalam sistem ajaran Islam merupakan rukun Islam yang keempat dan wajib ditunaikan oleh setiap pemeluk Islam yang mampu dengan ketentuan dan syarat-syarat tertentu. Ia merupakan salah-satu ajaran Islam yang mengandung nilai sosial karena pola peiaksanaannya berawal pada usaha pengumpulan harta dari orang yang mampu untuk digunakan dan diberikan kepada orang lain yang memerlukan, antara lain dengan tujuan memerangi kemiskinan dan meratakan jalur pendapatạn.
Dalam ajaran Islam, zakat yang diambil dapat berupa zakat fitrah, zakat tanaman, zakat hewan, zakat emas dan perak serta zakat perdagangan, yang masing-masing dengan ketentuan yang berbeda. Orang yang mengeluarkan harta zakat disebut muzakki dan penerimanya disebut mustahiq. Bagi muzakki berlaku ketentuan, bila hartanya telah mencapai jumlah tertenu, wajib dikeluarkan untuk kepentingan sosial. Prosentase yang diambil adalah : zakat fitrah sebesar $2 \frac{1}{2} \mathrm{~kg}$ bahan makanari setahun, zakat tanaman sebesar $10 \%$, zakat perdagangan sebesr $21 / 2 \%$, zakat emas atau perak sebesar $21 / 2 \%$, dan zakat hewan yang terdiri dari sapi, kambing, kerbau dengan ketentuan tertentu pula. Sedangkan mustahig, yaitu mereka yang berhak menerima zakat, terbagi dalam 8 golongan, yakni fakir, miskin, amil (orang yang mengumpulkan dan membagi zakat), muallaf (orang yang baru masuk Islam) budak-hamba sahaya; gharim (orang yang terbelit ikatan hutang), sabilillah (orang yang bepergian berjuang di jalan Allah), dan $\mathbf{I b n}$ sabil (orang yang bepergian dengan maksud baik dan kehabisan bekal perjalanan).

\section{Pengelolaan Zakat di Putukrejo}

Usaha untuk merelaisasi ajaran zakat di desa Putukrejo, telah lama dijalankan. Sebenarnya sudah sejak lama sebagian besar penduduk desa mengeluarkan zakat fitrahnya yang diberikan kepada ulama setempat setiap tahun sekali. Oleh ulama sebagian hasil zakat tersebut dibagikan kepada fakir-miskin dan sebagian lainnya menjadi hak miliknya. Pembagian zakat yang terpusat pada ulama tersebut, selain karena ulama adalah termasuk pihak yang berhak 
menerima zakat dalam golongan sabilillah dan amil zakat, juga dimaksudkan sebagai penghargaan yang tulus dari penduduk desa dan harapan mendapatkan berkah dari ulama tersebut. Di sini selain masalah hukum yang dijalankan, masalah kepemimpinan yang karismatik dari ulama memang faktor yang sangat menentukan.

Keadaan yang demikian itu berjalan hingga sekitar tahun 1960-an ketika pimpinan desa dan ulama setempat berusaha mengadakan perubahan pengelolaan zakat dengan membentuk sebuah badan yang bertugas mengolola zakat. Akan tetapi sampai tahun 1970 cara yang dipakai badan/panitia tersebut masih bersifat verbal, yakni dengan melaksanakan ajaran zakat dari kitab fikih tanpa memberikan penafsiranpenafsiran baru yang disesuaikan dengan arti pokok tujuan perintah zakat serta kebutuhan dan perkembangan masyarakat. Dalam periode itu zakat dikumpulkan oleh panitia dari para muzakki, kemudian dibagikan langsung kepada mustahiq, baik berupa uang maupun bahan makanan setahun sekali. Zakat yang diambil dalam periode itu adalah zakat fitrah dan sedikit zakat tanaman dan perdagangan.

Sekitar tahun 1970 timbul ide Kepala Desa Putukrejo untuk mengintensifikasikan pengelolaan zakat dan mengadakan perubahan, baik dalam sistem pelaksanaannya maupun personil yang menanganinya, sehingga hasil zakat dapat dirasakan manfaatnya olehmuzakki maupun mustahiq serta desa tempat tinggal mereka. Ide ini dilatarbelakangi oleh keterbatasan alokasi dana anggaran pembangunan desa dan kenyataan kurang bermanfaatnya hasil yang diperoleh dari pengelolaan zakat selama ini untuk mensejahterakan masyarakat dan memerangi kemelaratan dan kemiskinan, sebagaimana yang diajarkan oleh agama Islam. Kenyataan yang lebih penting lagi adalah anggapan sebagian besar ulama setempat yang menyadari bahwa Islam adalah agama pembangunan, dalam pengertian, Islam tidak menghambat pembangunan bahkan Islam mendorong cepatnya proses pembangunan.

Oleh Kepala Desa ide tersebut disampaikan kepada musyawarah ulama setempat sebelum dijadikan bahan pembicaraan dalam Rembug Desa untuk dijadikan keputusan pemerintah desa Putukrejo. Langkah yang dialuri Kepala Desa tersebut didasarkan pada kenyataan bahwa ulama mempunyai pengaruh yang menentukan di desa, sehingga setiap keputusan desa akan ditolak penduduk desa bila tanpa persetujuan dan restu ulama setempat. Semula ide tersebut ditolak oleh ulama, karena ia menyalahi tradisi keagamaan yang telah mapan dan terutama akan merugikan pihak-pihak yang selama ini mendapatkan keuntungan dari sistem pengelolaan zakat yang telah lama berjalan. Akan tetapi berkat keberanian dan ketabahan Kepala Desa memperjuangkan idenya, akhirnya ulama menerimanya dan bersama-sama dengan pimpinan desa menjabarkan ide tersebut dalam pelaksanaannya.

Di antara keputusan-keputusan yang diambil adalah membentuk Panitia yang lebih sempurna untuk lebih mengintensifkan pengelolaan zakat, meningkatkan pengambilan zakat tanaman dan perdagangan selain zakat fitrah dan menggunakan hasil zakat yang ter- 
kumpul untuk kepentingan desa beserta penduduknya. Dalam pelaksanaannya, keputusan terbentur pada masalah penafsiran hukum zakat yang selama ini ada, seperti menentukan hukum : apakah tanaman tebu itu zakatnya dimasukkan tanaman atau perdagangan? Siapakah yang wajib mengeluarkan zakat dan berhak menerima zakat di desa tersebut? Siapakah yang disebut fakir, miskin dan mampu itu? Dapatkah zakat tersebut digunakan untuk dana pembangunan desa?.

Masalah-masalah tesebut sempat menimbulkan perbedaan pendapat yang tajam di antara ulama-ulama setempat dan karena tidak tercapai kesepakatan dalam menentukan hukum, dibawalah masalah tersebut ke Syuriah Nahdlatul Utama kabupaten Malang. Karena ternyata Syuriah tidak dapat memutuskannya, akhirnya masalah tersebut disampaikan kepada Prof, Kiyai Haji Syafi'i Al Karim, Rektor IAIN Sunan Ampel waktu itu. Oleh beliau masalah tersebut dapat dipecahkan dengan memberikan penetapan hukum yang diterima oleh seluruh ulama setempat.

Di antara masalah hukum yang disepakati itu adalah :

1. Tanaman tebu tidak dapat dimasukkan ke dalam tanaman murni, karena dalam proses penanamannya banyak bergantung pada kredit koperasi, sebagian tanah yang dipergunakan bukan tanah sendiri dan bukan tanaman yang mengenyangkan. Oleh karena itu zakatnya termasuk dalam zakat perdagangan, yaitu $2 \frac{1}{2} \%$.

2. Untuk menentukan kriteria yang wajib mengeluarkan zakat dan berhak menerima zakat diambil kriteria sederhana, yakni : orang fakir adalah orang yang tidak mempunyai apa-apa, pendapatannya tidak mencukupi kebutuhan minimal sehari-hari, seperti pangan, sandang dan papan. Orang miskin adalah orang yang tidak punya/mampu, tetapi mempunyai tanah garapan, radio, sepeda dan ternak piaraan. Orang yang mampu adalah mereka yang tidak termasuk dalam kedua kategori tersebut. Di desa Putukrejo ditetapkan pula bahwa yang berhak menerima zakat adalah fakir, miskin, amil dan sabilillah saja. Golongan lain yang berhak menerima tidak terdapat lagi di desa tersebut.

3.Zakat dapat dipergunakan untuk kepentingan desa dan pembangunannya, karena pembangunan desa dapat dimasukkan dalam sabilillah. Termasuk dalam kriteria sabilillah yang dipahami sebagai jalan kebaikan antara lain : jalan umum, jembatan, kesehatan, pendidikan, peribadatan, administrasi, MUUAD, dan keamanan/ kesejahteraan.

Setelah masalah-masalah yang berkenaan dengan hukum diselesaikan, dimulailah pelaksanaan pengelolaan zakat dengan sistem yang baru yang disesuaikan dengan gerak pembangunan yang sedang berjalan di desa-desa seluruh Indonesia. Hasil yang dicapai dengan zakat sebagai sumber dananya tersebut ternyata sangat menggembirakan, baik pembangunan spiritual maupun material. Gerakan ini semakin mantap, ketika terbentuk MUUAD pada tahun 1976, kependekan dari "Musyawarah Ulama, Umara, Aghniya Desa", Putukrejo, yang mengikutsertakan tokohtokoh yang berpengaruh di desa, yakni Ulama, Umara atau pimpinan desa dan Aghniya atau orang-orang kaya yang wajib mengeluarkan zakat. 


\section{Hasil Zakat Tahun 197I - 1978}

Secaragaris besar, hasil-hasil yang dicapai seläna periode 1971 - 1978 dari zakat untuk pembangunan desa dapat diterangkan sebagai berikut.

Tahun 1971 panitia amil zakat berhasil mengumpulkan uang dari zakat perdagangan tebu sebanyak Rp. $2.000 .000 ; 00$ ditambah uang desa sebesar Rp. 350.000,00 digunakan sebagai daná pembangunan desa. Dari jumlah Rp. 2.350.000,00 tersebut, Rp. $1.000 .000,00$ diputar untuk perdagangan, Rp. 1.110.000,00 untuk pembuatan Pos Hansip, Rp. 150.000,00 untuk membantu pemugaran Madrasah dan Rp. 50:000,00 untuk melengkapi alatalat kantor.

Keputusan untuk menggunakan uang zakat bagi keperluan-keperluan di atas, dan bahkan diberikan langsung kepada fakir miskin maupun amil, ditetapkan setelah melalui musyawarah ulama, umara, muzakkim amil dan fakirmiskin. Dalam musyawarah tersebut diminta kerelaan fàkir miskin untuk menyerahkan sebagian zakatnya untuk pembangunan desa yang dikategorikan sebagai sabilillah. Sedangkan para amil zakat yang terdiri dari ulama dan umara setempat, biasanya menerima bagiannya yang kemudian secara langsung diberikan untuk dana pembangunan.

Sedang dari hasil zakat tanaman jagung dan padi pada tahun 1971 tersebut, Panitia berhasil mengumpulkan padi sebanyak $3.000 \mathrm{~kg}$, jagung $5.116 \mathrm{~kg}$ dan sebagian lagi setiap datangnya musim paceklik. Dari zakat fitrah terkumpul padi sebanyak $6.500 \mathrm{~kg}$ dan jagung sebanyak $1.500 \mathrm{~kg}$ yang langsung dibagikan menjelang hari raya Idul Fitri.
Dalam tahun 1972, dari hasil pungutan zakat 1972 dan laba pemutaran uang zakat tahun 1971 terkumpul uang sejumlah Rp. 3.719.000,00 yang digunakan untuk pengerasan jalan desa sepanjang 800 meter dengan biaya Rp. $700.000,00$. Dari zakat fitrah terkumpul padi sebanyak $3.600 \mathrm{~kg}$ dan jagùng sebanyak $2.950 \mathrm{~kg}$.

Pada tahun 1973 terkumpul uang zakat sebesar Rp. 7.019.000,00 yang dibagikan berupa barang sebagai modal kerja bagi fakir miskin, yaitu sebanyak 127 ekor sapi seharga Rp. 4.879.000,00; 200 ekor kambing seharga Rp. $1.100 .000,00 ; 40$ buah sepeda seharga Rp. $800.000,00$; 5 buah mesin jahit seharga Rp. 102.000,00. Dari zakat tanaman terkumpul padi sebanyak $5.000 \mathrm{~kg}$ dan jagung $4.500 \mathrm{~kg}$; sedang dari zakat fitrah, beras sebanyak 1.906 $\mathrm{kg}$ dan jagung sebanyak 8.331.

Pada tahun 1974 diputuskan bahwa zakat tanaman yang biasanya diwujudkan dengan barang, diganti uang yang akan dipergunakan untuk kepentingan pembangunan desa. Dari hasil sumber tadi terkumpul uang sebanyak Rp. $6.175 .000,00$ yang dipergunakan untuk pembuatan rumah fakir miskin sebanyak 31 buah, dan pengerasan jalan sepanjang 1.000 meter dengan biaya sebesar Rp. 2.300.000,00. Sedangkan dari zakat fitrah terkumpul padi sebanyak $2.816 \mathrm{~kg}$ dan jagung sebanyak $8.556 \mathrm{~kg}$. Rumah yang dibangun dan diberikan kepada penduduk yang fakir, berukuran $5 \times 7$ meter, dibangun secara gotong-royong, yang materialnya diambilkan dari uang zakat; dibuat memenuhi persyaratan kesehatan, terletak di atas tanah desa yang berada di pinggir jalan utama desa. Tujuan pendirian 
rumah tersebut selain untuk memenuhi salah satu kebutuhan minimal seseorang, yaitu papan, juga dimaksudkan untuk mengenalkan penduduk desa satu tipe rumah sehat dan serasi.

Pada tahun 1975 terkumpul uang zakat sebesar Rp. 1.900.000,00 yang kemudian ditambah uang kas desa Rp. $350.000,00$ digunakan untuk pembuatan rumah sebanyak 5 buah seharga $R p$. $875.000,00$, pengerasan jalan sepanjang 1.200 meter seharga Rp.1.275.000,00 dan pembangunan madrasah sebesar Rp. $100.000,00$. Dari zakat tanaman terkumpul beras sebanyak $7.000 \mathrm{~kg}$ dan jagung sebanyak $9.250 \mathrm{~kg}$. Sedangkan dari zakat fitrah terkumpul beras sebanyak $3.000 \mathrm{~kg}$ dan jagung $1.250 \mathrm{~kg}$.

Pada tahun 1976 terkumpul uang zakat sebesar Rp.800.000,00 yang ditambah uang desa Rp.350.000,00 digunakan untuk pengerasan jalan sepanjang 700 meter dengan biaya sebesar Rp.1.004.500,00 kesejahteraan masyarakat $\mathrm{Rp} .75 .000,00$, pendidikan Rp.50.000,00 dan alat-alat kantor Rp.24.500,00. Dari hasil zakat tanaman terkumpul beras sebanyak $5.000 \mathrm{~kg}$, jagung $4.230 \mathrm{~kg}$ dan dari zakat fitrah beras sebanyak $2.150 \mathrm{~kg}$ serta jagung sebanyak $3.200 \mathrm{~kg}$.

Pada tahun 1977 terkumpul uang zakat sebesar Rp. $250.000,00$ yang ditambah uang desa Rp.350.000,00 digunakan untuk membangun gudang zakat dengan biaya Rp.1.400.000,00; kesejahteraan masyarakat $\mathrm{Rp}$. $150.000,00$., dan melengkapi alat-alat kantor zakat Rp.50.000,00. Dari hasil zakat tanaman terkumpul beras sebanyak $6.000 \mathrm{~kg}$ dan jagung $3.41 .5 \mathrm{~kg}$, sedangkan dari zakat fitrah terkumpul $1.700 \mathrm{~kg}$ beras dan $4.250 \mathrm{~kg}$ jagung.
Pada tahun 1978 terkumpul uang zakat sebesar Rp.1.400.000,00 yang kemudian ditambah uang dsa $\mathrm{Rp}$. $550.000,00$, digunakan untuk menyempurnakan pembangunan gedung zakat sebesar Rp.1.400.000,00, kesejahteraan masyarakat sebesar Rp.300.000,00, pendidikan Rp.200.000,00 dan administrasi sebesar Rp.50.000,00. Dari zakat tanaman terkumpul padi sebanyak $14.900 \mathrm{~kg}$ dan jagung $5.750 \mathrm{~kg}$, sedangkan dari zakat fitrah terkumpul beras sebanyak $5.750 \mathrm{~kg}$ dan jagung $3.950 \mathrm{~kg}$. Untuk tahun 1979 diputuskan oleh MUUAD bahwa uang zakat tanaman dan zakat perdagangan akan diwujudkan untuk memperluas jaringan listrik yang sudah ada di desa tersebut.

Dari data yang dikemukakan, terlihat dengan jelas bahwa uang yang didapat dari zakat ternyata berjumlah jauh lebih besar daripada dana pembangunan yang tersedia pada pemerintah desa tersebut.

Dalam hubungannya dengan usaha memerangi kemiskinan, dana yang diambilkan dari zakat mencatat adanya penurunan jumlah fakir-miskin di desa tersebut sejak tahun 1971 hingga tahun 1977. Pada tahun 1971 tercatat sebanyak $527 \mathrm{kk}$ fakir miskin dan tahun 1977 tercatat $380 \mathrm{kk}$ yang berhak menerima zakat. Ini berarti bahwa dengan dana zakat rata-rata setiap tahunnya dapat dikurangi secara relatif sebanyak 24 kepala keluarga miskin.

Selanjutnya pada bulan April 1979, dirintis oleh Badan Amil Desa Putukrejo, telah dicapai kesepakatan antara pamong desa, para ulama dan kalangan masyarakat dermawan, untuk mendirikan suatu Yayasan bernama "Yayasan Sosial Fakir Miskin" (YASOFAMI). Modal kerja diperoleh dari : 
Badan Amil Zakat

Rp. $\quad 525.000,00$

Sumbangan dermawan

Lain-lain

Rp. $1.750 .000,00$

Rp. $350.000,00$

Jumlah

Rp.2.625.000,00

Uang sejumlah tersebut diwujudkan menjadi satu buah mesin slijp untuk gabah, jagung dan gaplek. Inilah sebagian modal usaha dari yayasan tersebut untuk dikembangkan lebih lanjut dalam rangka membantu peningkatan sosialekonomi dan pendidikan golongan miskin.

\section{Faktor-faktor Pendorong dan Peng- hambat}

Berhasil tidaknya suatu tindakan seringkali tergantung pada banyak tidaknya dorongan maupun hambatan yang mempengaruhi tindakan tersebut. Demikian pula pengelolaan zakat yang terdapat di desa Putukrejo. Bila usaha yang dijalankan di Putukrejo dinilai berhasil, maka berdasarkan hasil pengamatan dan wawancara selama penelitian, didapatkan beberapa faktor yang berpengaruh terhadap berhasil/tidaknya usaha tersebut.

Faktor yang mendorong berhasilnya pengumpulan zakat untuk dana pembangunan di desa Putukrejo, diantaranya ialah :

1. Adanya banyak persamaan di kalangan penduduk Putukrejo di bidang pendidikan, pekerjaan, asal keturunan, orientasi keagamaan dan kepentingan.

2. Struktur masyarakatnya yang agamis, sehingga memungkinkan digunakannya motif-motif keagamaan untuk menggerakkan rakyatnya. Di samping itu keinginan sebagian besar pemeluknya untuk menghayati dan mengamalkan ajaran agamanya dalam kehidupan sehari-hari.
3. Adanya keterlibatan seluruh penduduk desa dalam proses yang sedang berjalan, terutama terbinanya kerjasama antara ulama, umara dan aghniya desa. 4. Adanya iklim yang baik untuk kegiatan pengumpulan zakat yang diciptakan sejak dari daerah tingkat I sampai daerah tingkat II beserta tingkat-tingkat di bawahnya.

5. Kesediaan para ulama, umara dan aghniya yang menjadi contoh teladan dalam mengeluarkan zakat dan amalanamalan lainnya, sesuai dengan ajaran agama dan falsafat Jawa ing ngarso sung tulada, ing madya mangun karsa, tut wuri hàndayani.

Sedangkan faktor yang menghambat antara lain:

1. Kurang intensifnya pelaksana pengelola yang disebabkan kurang adanya tenaga ahli yang mengatur administrasinya.

2. Perencanaan yang terialu sederhana sehingga tidak mampu menjangkau halhal yang lebih jauh dan luas.

3. Terbatasnya sumber dana, dan

4. Sulitnya pengawasan pelaksananya yang antara lain disebabkan belum adanya hukum positif yang ditetapkan.

Demikian sedikit yang bisa terekam tentang pelaksanaan zakat di desa Putukrejo sepanjang pengamatan yang sekilas dan tidak begitu mendalam. Untuk lebih jelasnya, bersama ini disertakan beberapa bagan dan rekapitulasi pengelolaan zakat tersebut.

Skema Unsur-unsur Pembangunan Desa Putukrejo

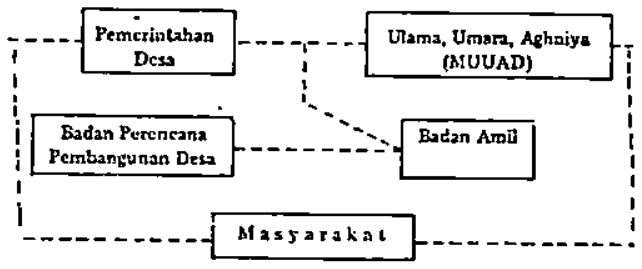




\section{MASALAH DAN PEMECAHAN- NYA}

1. Sebagaimana kita ketahui, tujuan pembangunan ada tiga, yaitu pertumbuhan ekonomi, kepercayaan kepada diri sendiri dan keadilan sosial. Bagi negara yang sedang berkembang seperti Indonesia, keadilan sosial harus lebih ditekankan. Pemerataan hasil pembangunan kepada seluruh rakyat merupakan motivasi dan dorongan yang sangat hebat bagi pembangunan di negaranegara yang sedang berkembang. Merasa diperlukan secara adil dan dapat menikmati hasil jerih payahnya, pasti akan merupakan dorongan untuk ikut menanggung beban pernbangunan.

Dengan pemerataan hasil pembangunan, percaya kepada diri sendiri akan makin tumbuh di kalangan masyarakat. Kita mengetahui bahwa percaya kepada diri sendiri merupakan modal pokok bagi kehidupan, baik perorangan maupun bangsa. dengan timbulnya kepercayaan kepada diri sendiri di kalangan sekelompok masyarakat, diharapkan ia akan sanggup mengerjakan pekerjaan-pekerjaan yang tidak dapat dilaksanakan oleh kelompok-kelompok masyarakat dan yang lebih besar yang tidak mempunyai kepercayaan kepada kemampuan diri sendiri. Konsekuensinya pembangunan harus dilakukan dari bawah, dan lapisan masyarakat bawah itulah yang harus menjadi sasaran utama dan pertama dalam pembangunan.

Dengan ini jelas bahwa pernyataan 'biar kuenya besar dulu, baru nanti dibagi" tidak dapat diterima. Alasan pernyataan ini adalah kalau "kuenya belum besar" maka pemerataan itu hanya merupakan "pemerataan kemiskinan". Pendapat ini didasarkan atas persangkaan bahwa sekalipun modal hanya dikuasai oleh beberapa orang atau beberapa kelompok masyarakat, akhirnya toh rakyat akan merasakan hasil pembangunan dengan pemutaran modal itu. Pendapat ini tidak tepat karena orang lupa bahwa pola konsumsi orang-orang kaya itu harus melalui pola-pola tertentu yang sulit diubah; demikian juga pòla dan organisasi produksi itu membawa pola konsumsi dan distribusi yang sulit diubah pula.

Dengan itu proses selanjutnya akan menjadi "yang kaya semakin kaya dan yang miskin semakin miskin". Ditambah lagi dengan watak kekayaan yang tidak akan memberikan kepuasan kepada penyandangnya. Semakin kaya orang itu, ia semakin merasa kekurangan. Dan setelah kebutuhan-kebutuhan pokok tercukupi, maka kekayaannya pasti akan dibelanjakan untuk kebutuhan-kebutuhan yang diadaadakan. Dari seberang lain rakyat, yang sebagian besar miskin itu, tidak dapat hanya disuruh menyaksikan kejadian yang pincang itu dan diberi harapan-harapan yang kabur bahwa kemudian hari mereka juga bisa menjadi orang yang sanggup berkonsumsi tinggi, kalau tidak didahului dengan kedengkian dan keputusasaan.

Presiden Soeharto dalam Pidato Kenegaraan 16 Agustus 1978 telah menyatakan bahwa pada tahun-tahun selanjutnya pembangunan kita di Indonesia akan makin mempertegas wajah keadilan sosial melalui usaha-usaha pemerataan pembangunan. Demikiatı juga seperti ditunjukkan oleh GBHN, dalam melanjutkan pembangunan ekonomi sosial kita akan tetap maju dengan menjaga keserasian pemerataan, pertumbuhan dan stabilitas. Adapun pemerataan yang akan ditempuh itu melalui delapan jalur, yaitu : (1) Peme- 
rataan pemenuhan kebutuhan pokok rakyat, (2) Pemerataan kesempatan memperoleh pendidikan dan pelayanan kesehatan, (3) Pemerataan pembagian pendapatan, (4) Pemerataan kesempatan kerja, (5) Pemerataan kesempatan berusaha, (6) Pemerataan berpartisipasi dalam pembangunan, khususnya bagi generasi muda dan kaum wanita, (7) Pemerataan penyebaran pembangunan di seluruh wilayah tanah air, dan (8) Pemerataan kesempatan memperoleh keadilan.

2. Untuk mencapai sasaran, yaitu untuk meratakan hasil pembangunan, dan dengan itu dapat menimbulkan kepercayaan pada diri, sendiri, maka motivasi-motivasi yang tepat harus diusahakan. tujuan pembangunan yang baik belum tentu dapat menggerakkan masyarakat untuk bangkit mengambil bagian, jika motivasi-motivasi yang tepat tidak dapat kita peroleh.

Indonesia adalah negara nusantara, bukan negara benua, yang mengandung pelbagai macam adat kebiasaan dan corak kebudayaan. Dan motivasi-motivasi yang dapat menggerakkan hati nurani masyarakat harus dapat digali dari adat kebiasaan dan kebudayaan yang hidup dalam pelbagai kelompok masyarakat Indonesia yang bhinneka tetapi $e k a$ itu. Dan karena masyarakat Indonesia adalah masyarakat agamis, maka motivasi-motivasi agama, saya kira, perlu digali untuk membangkitkan gairah pembangunan. Sudah barang tentu harus disertai dengan ketepatan pengelolaan, yang berupa rapinya organisasi dan kontrol, di samping ketrampilan dan kejujuran pengelolanya. Selain itu masyarakat juga harus segera merasakan hasil jerih payahnya, sekalipun sangat sederhana, supaya mereka sadar bahwa jerih-payahnya itu juga membawa hasil yang dapat ia nikmati.

Berbicara soal motivasi, maka transmigrasi di desa Putukrejo belum menarik. Hal ini mungkin disebabkan mereka tidak merasa terdesak oleh kebutuhankebutuhan sehari-hari, karena memang kebutuhan-kebutuhan mereka terbatas. Ditambah lagi dengan keinginan mereka untuk selalu hidup berkelompok yang, sudah barang tentu, tidak begitu banyak menghadapi risiko. "Makan tidak makan asal kumpul", rupa-rupanya masih menjadi pegangan bagi mereka. Juga barangkali karena kurang kesadaran mereka tentang transmigrasi yang dianggap sebagai suatu tindakan yang hina.

Dalam hal ini, rasa-rasanya perlu juga dicoba untuk memberikan motivasimotivasi agama untuk menggerakkan transmigrasi di desa seperti Putukrejo ini. Pernah saya terangkan kepada mereka bahwa Sunan Ampel di Jawa Timur, Sunan Muria di Jawa Tengah, Sunan Gunungjati di Jawa Barat, dan masih banyak lagi orang-orang besar dalam sejarah Islam di Indonesia adalah bukan orang-orang asli Indonesia. Mereka adalah orang-orang yang hijrah (transmigrasi) dari Gujarat, India, entah asalnya dari Persia atau dari Hadramaut, Yaman Selatan atau Afrika Utara. Karena mereka hijrah dan transmigrasi ke Indonesialah, maka mereka itu "dikeramatkan" orang. Oleh karena itu apabila saudara-saudara ingin dikeramatkan orang, bertransmigrasilah! Dan sudah barang tentu motivasi-motivasi lain yang beraspirasi agama dapat juga digali untuk menggerakkan pembangunan di desa seperti Putukrejo ini.

Demikian juga untuk menggerakkan pramuka umpamanya, tapi alhamdulilah pramuka sudah baik di desa Putukrejo; di daerah-daerah yang agamis, 
tidak usah diterangkan bahwa Bapak Pramuka itu Lord Baden Powel. Tetapi lebih baik diterangkan bahwa Bapak Pramuka adalah Ali bin Abi Thalib, keponakan dan menantu Nabi Muhammad SAW. Kehidupan dan tingkah laku mulia yang dimiliki oleh Ali bin Abi Thalib itulah yang akan dicontoh, umpamanya dalam hal mengutamakan kepentingan orang lain, cinta kepada agamn dan tanah air, suka membantu orang lain, jujur, giat bekerja dan sebagainya. Saya rasa dengan cara ini, kepramukaan juga akan lebih maju, dan bagi orang-orang Islam akan mendapatkan pegangan yang lebih kokoh.

3. Desa Putukrejo dalam usaha membangun desanya, mengingat sangat terbatasnya dana pembangunan untuk desanya, berusaha mencari dana dengan menggerakkan motivasi-motivasi yang hidup di kalangan masyarakatnya, dengan tidak mengejutkan pola pikiran dan pola lakunya. Karena itulah dana pembangunan desa diambil dari pemungutan zakat.

Dengan pemungutan zakat, seperti yang dapat dicatat perkembangannya dari tahun 1974-1978, ternyata desa Putukrejo telah dapat mendekati sasaran pembangunan yang berupa pemerataan. Dari uraian di atas, kita mengetahui bahwa dengan zakat, kebutuhan pokok rakyat dapat dicukupi, perumahan dapat dibangun sebanyak 36 buah dan rehabilitasi banyak rumah penduduk miskin. Kebutuhan pangan dicukupi dengan pembagian zakat fitrah pada hari raya Idul Fitri dan pembagian zakat hasil pertanian dalam musim paceklik. Demikian juga dalam bidang pemeratsan untuk memperoleh pendidikan dan kesehatan dapat dijangkau, karena sebagian hasil zakat juga digunakan untuk dana pendidikan, baik untuk membangun tempat-tempat pendidikan, untuk beasiswa, dan juga untuk keperluan kesehatan dan kesejahteraan umumnya. Adapun tentang pemerataan pembagian pendapatan, adalah sesuai dengan pelaksanaan zakat sendiri. Tentang pemerataan kesempatan kerja, dapat dicapai dengan mewujudkan hasil zakat dalam bentuk barang-barang modal, seperti lembu, kambing, mesin jahit dan mesin slijp. Cara ini juga mencakup pemerataan kesempatan berusaha dan kesempatan kerja. Dengan pelaksanaan zakat ternyata sedikit atau banyak juga dapat meratakan partisipasi dalam pembangunan dan penyebaran usaha-usaha pembangunan di daerah pedesaan itu. Pelistrikan dan pengerasan jalan akan membawa pengaruh yang tidak kecil terhadap hidup dan kehidupan masyarakat desa. Adalah jelas bahwa zakat dapat mengurangi kemiskinan dengan nyata di desa Putukrejo.

Salah satu hasil lagi yang diperoleh dengan pelaksanaan zakat di desa Putukrejo ialah tumbuhnya solidaritas di antara penduduk. Di samping itu, karena di de\$a Putukrejo tidak ada orang yang kelaparan, sedangkan orang-orang kaya dan pemerintah desanya tampak sekali memperhatikan nasib orang-orang miskin, ditambah lagi dengan pendidikan akhlak dan moral yang sangat baik, maka ternyata di desa Putukrejo juga tidak ada pencurian. Kalau toh ada pencurian, menurut keterangan Kepala Desa, maka hal itu dilakukan oleh orang dari luar desa Putukrejo, dan yang dicuri hanya ayam. Dengan demikian zakat dapat mengurangi kriminalitas. 
4. Kalau diingat bahwa kekayaan itu juga mempunyai fungsi sosial, maka Islam juga mengajarkan selain memberikan zakat yang beraneka-ragam juga menyuruh orang supaya memberikan wakaf, hibah, nazar untuk memberikan sesuatu kepada orang lain apabila maksudnya yang baik dapat tercapai, dan kifarah, yaitu memberi makan kepada fakir miskin ketika orang melakukan. suatu pelanggaran tertentu. Jika hal-hal semacam ini dilaksanakan, saya rasa pemerataan hasil dan beban pembangunan akan makin cepat tercapai. Sudah barang tentu hal ini memerlukan penggalian motivasi-motivasi yang tepat di samping peningkatan pembangunan di bidang ekonomi.

5. Sungguhpun dengan pelaksanaan zakat di desa Putukrejo delapan jalur pemerataan sedikit atau banyak dapat terjangkau, tetapi sebenarnya penghasilan rakyat desa Putukrejo sulit ditingkatkan kalau mereka tergantung kepada pertanian saja, karena rata-rata penduduk desa hanya mempunyai 0,244 ha tanah yang sudah barang tentu jauh dari cukup. Untuk lebih meningkatkan penghasilan rakyat desa itu, harus ditempuh cara memperluas usaha masyarakat dengan memasukkan industri yang bisa mengolah hasil pertanian tersebut. Demikian juga bisa dimasukkan pembikinan alat-alat pertanian, yang sudah barang tentu bukan hanya untuk mencukupi keperluan desa itu, tapi juga dicarikan pemasaran di daerah-daerah lain. Demikian juga peternakan belut juga cocok untuk daerah ini. Demikianlah menurut keterangan pejabat Kantor Perindustrian Provinsi Jawa Timur.

Selain itu karena, memang tanah sangat terbatas, maka hendaknya disa- darkan supaya tanah tidak diwaris dengan dibagi-bagi, karena dengan cara ini pemilikan tanah akan makin kecil dan akan makin mudah terjual kepada orang luar. Oleh karena itu dalam pelaksanaan waris di desa Putukrejo hendaknya bukan tanahnya yang dibagi-bagi, tetapi hasil garapan tanáh itulah yang dibagi-bagi menurut ketentuan waris. Sudah barang tentu hal ini memerlukan kesadaran dari masyarakat Putukrejo.

6. Sebagaimana diketahui, sekalipun di desa Putukrejo ada Tharikat Nagsyabandiyah, tetapi ternyata tidak terdapat konflik antara pengikut Naqsyabandiyah dengan bukan-Naqsyabandiyah. Perlu dijelaskan adanya suatu kebiasaan bahwa pemunculan sesuatu paham biasanya membawa tindakan ekstrimitas. Tetapi di desa Putukrejo timbulnya aliran tasawuf Naqsyabandiyah tidak menimbulkan pertentangan karena adanya hubungan kekeluargaan antara pemimpin desa dengan guru Tharikat Nagsyabandiyah itu. Kiyai Qasim, pemimpin Tharikat Nagsyabandiyah, adalah menantu Lurah Desa Putukrejo. Selain itu tidak terjadinya pertentangan juga karena paham agama yang dominan di desa itu adalah Nahdlatul Ulama yang sangat toleran terhadap aliran tasawuf. Selain dari itu karena pengaruh dan wibawa Lurah yang lebih menekankan kepada kepentingan desa, maka pertentangan tidak terjadi. Lebih daripada itu, untuk menjaga kesatuan dan kerukunan masyarakat desa Putukrejo, paham atau aliran agama apa pun yang ada di desa itu hendaknya juga dipergunakan sebagai alat politik.

7. Sebagaimana diterangkan di atas pengetahuan umum dan pendidikan 
yang lebih tinggi kurang mendapat perhatian desa itu. Hal itu disebabkan mungkin karena dua hal. Pertama, mereka khawatir bahwa dengna pengetahuan umum itu penghayatan agama mereka menjadi berkurang. Dan alasan keduanya, kalau anak-anaknya dimasukkan ke sekolah umum, mereka nanti ingin menjadi pegawai negeri dan tidak bisa membantu orang tuanya.

Oleh karena untuk meningkatkan taraf hidup rakyat Putukrejo diperlukan adanya industri, maka pengetahuan umum mutlak dibutuhkan. Tetapi dengan mempertimbangkan kekhawatirkan orang-orang tua di Putukrejo terhadap iman anak-anaknya, maka untlk memperoleh pengetahuan umum itu lebih baik dianjurkan supaya anakanaknya dimasukkan di sekolah umum yang terdapat dalam lingkungan Pondok Pesantren, seperti di Tebuireng, Rejoso, Kediri dan tempat-tempat lain di sekitar desa itu. Dengan demikian di samping anak-anak dapat memperoleh pengetahuan umum, agamanya juga tetapi terpelihara karena hidup dalam lingkungan pesantren. Adapun kekhawatiran yang kedua, perlu dijelaskan bahwa jika anak-anaknya menjadi anak-anak pandai maka kehidupannya sendiri akan lebih baik, atau bahkan bisa membantu membiayai orang tuanya yang sudah tua atau saudara-saudaranya yang memerlukan bantuan biaya; dan dengan demikian dapat membantu orang tuanya sekalipun tidak dalam bidang pertanian. Atau mungkin juga karena memperoleh pelbagai macam ketrampilan dan kembali ke kampungnya, mereka bisa merintis usaha-usaha industri yang sesuai dengan keperluan kampungnya.
8. Jika orang ingin menilai keberhasilan pembangunan di desa Putukrejo dengan jalan pemungutan zakat, maka hal ini disebabkan karena beberapa faktor. Di antaranya ialah adanya banyak persamaan di kalangan penduduk Putukrejo di bidang pendidikan, pekerjaan, asal keturuanan dan orientasi keagamaan. Ditambah lagi struktur masyarakatnya yang agamis, sehingga memungkinkan digunakannya motifmotif keagamaan untuk menggerakkan pembangunan. Disamping itu juga kerja-sama yang erat antara pemerintah dan pemimpin-pemimpin masyarakat bersama-sama dengan orang-orang kaya. Adanya orang-orang kaya yang secara langsung ikut memikirkan nasib orang-orang miskin inilah bahwa dalam melaksanakan zakat, pamong desa, para ulama dan orang-orang kaya memberi contoh. Masih ada lagi satu faktor yang menguntungkan pemungutan zakat di Putukrejo, yaitu adanya iklim yang baik lagi kegiatan pengumpulan zakat yang diciptakan oleh pemerintah Kabupaten dan Provinsi. Sebenarnya pemungutan zakat bisa lebih ditingkatkan lagi, dengan pengelolaan yang lebih rapih, perencanaan yang lebih matang dan peningkatan penghasilan rakyat desa Putukrejo.

\section{KESIMPULAN}

1. Pemerataan adalah salah satu tekanan yang ingin dicapai oleh usaha pembangunan kita.

2. Untuk mencapai pemerataan, di samping kerapian dalam pengelolaan, kejujuran atau ketrampilan, motivasi-motivasi untuk menggerakkan pembangunan bagi suatu daerah perlu digali dan ditumbuhkan. 
3. Desa Putukrejo yang seantero penduduknya Muslim dan suku Madura, sudah berada di jalan yang tepat, di mana motivasi zakat dibangkitkan untuk membangun desa.

4. Untuk lebih meningkatkan hasil zakat, pengaturan pengelolaan zakat harus lebih ditingkatkan.

5. Dengan usaha apa pun, dilihat dari penghasilan perorangan, rakyat desa Putukrejo tidak bisa berpenghasilan melebihi hasil maksimum yang mungkin dapat diperoleh dari hasil pertanian perdagangan dan jasa yang dilakukan oleh rakyatnya seperti sekarang ini.

6. Oleh karena itu dua hal harus dilakukan, yaitu transmigrasi dan industrialisasi yang sesuai dengan kemampuan desa.

7. Pendidikan ketrampilan dan umum perlu digiatkan di desa Putukrejo.

8. Agar pemilikan tanah tidak menjadi makin sempit, pelaksanaan hukum waris supaya diatur sedemikian rupa, sehingga bukan tanahnya, tetapi hasil garapan tanahnya, yang waris.

9. Apa yang dilakukan dengan penarikan zakat di desa Putukrejo itu bisa juga diterapkan di desa dan daerah lain di Indonesia yang mempunyai struktur dan isi yang hampir sama seperti desa Putukrejo itu.

10. Analog dengan Putukrejo dalam hal pentingnya motivasi dalam pembangunan, barangkali dapat juga diterapkan dengan menggali motivasimotivasi agama Hindu untuk menggerakkan pembangunan di Bali, motivasi-motivasi yang bersumber pada agama Kristen untuk mengge- rakkan pembangunan di daerah Minahasa, dan motivasi-maotivasi yang beremanasi dari agama Kristen Katolik untuk menggerakkan pembangunan di daerah Timor-Timur.

Demikianlah laporan survei desa Putukrejo, Malang Selatan. Mudahmudahan ada juga manfaatnya.

\section{LAMPIRAN 1}

Peta Daerah Pemukiman dan Jalan Desa Putukrejo

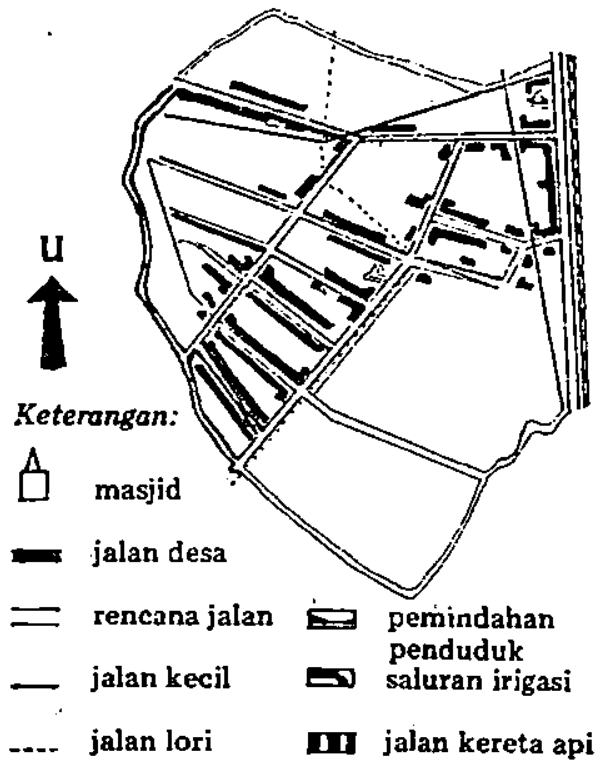

\section{LAMPIRAN 2}

Nama-nama Pamong Desa Putukrejo

1. H.Mahmuji - Kepala Desa

2. H. Junaedi - Carik.

3. Rosidah - Kamituo I.

4. Paksana - Kamituo II.

5. Sufaat - Kapetengan I.

6. Madrai - Kapetengan II.

7. Ponirin - Kabayan I.

8. Nasuha - Kabayan II.

9. H. Ali Umar - Kuwowo I.

10. Pakmunarsih - Kuwowo II.

11. Hariudin - Modin. 
Nama-nama Ulama Desa Putukrejo

1. KH. Abdurrahman 55 tahun

2. KH. Nur Hamidi 52 tahun

3. KH. Abu Abbas 52 tahun

4. KH. Qasim 38 tahun

5. KH. Husni 40 tahun

6. H. Romzi 42 tahun

7. Djunaedi 44 tahun

8. H. Syamsuddin 40 tahun

9. H. Mashudi 40 tahun

\section{LAMPIRAN 3}

Skema Pelaksanaan Kerja Badan

Amil Zakat Desa Putukrejo

\begin{tabular}{|c|}
\hline MUUAD \\
Musyawarah Ulama, Umara, \\
Aghniya Desa
\end{tabular}

Rembug-Desa

Lembaga Sosial Desa

BAZ

Badan Amil Zakat

Pelaksana

\begin{tabular}{|c|c|}
\hline Pelaksana & Pelaksana \\
Pembina & Pemanfaatan \\
\hline
\end{tabular}

\section{LAMPIRAN 4}

Musyawarah Ulama, Umara, Aghniya Desa (MUUAD)

\begin{tabular}{|c|c|}
\hline \multicolumn{2}{|c|}{$\begin{array}{c}\text { Pelindung } \\
\text { Kepala Desa : H. Mahmudji }\end{array}$} \\
\hline $\begin{array}{l}\text { Ketua } \\
\text { 1. KH. Nur } \\
\text { 2. KH. A. }\end{array}$ & $\begin{array}{l}\text { Hamidi } \\
\text { Qasim }\end{array}$ \\
\hline \begin{tabular}{|l|} 
\\
Bendahara \\
1. H. Romzi Mursidi \\
2. H. Abdul Wahab
\end{tabular} & \begin{tabular}{|c} 
Penulis \\
1. H.A. Djunaidi \\
2. K.H.A. Qasim \\
\end{tabular} \\
\hline \multicolumn{2}{|c|}{ Pembantu/Anggota } \\
\hline $\begin{array}{ll}\text { 1. K.H. Abu Abas } & 5 . \\
\text { 2. K.H. Husni } & 6 . \\
\text { 3. K.H. Badaruddin } & 7 . \\
\text { 4. H. Chalifah } & 8 .\end{array}$ & $\begin{array}{l}\text { H. Romzi Mursidi } \\
\text { H. Ali Mustofa } \\
\text { H.M. Kamal } \\
\text { H. Abdulkadir }\end{array}$ \\
\hline
\end{tabular}

LAMPIRAN 5

Lembaga Sosial Desa (LSD) Putukrejo

Ketua :

1. K.H.A. Djunaidi

2. Mohammad Soleh

\begin{tabular}{|c|c|}
\hline $\begin{array}{l}\text { Penulis } \\
\text { 1. Abdurohim } \\
\text { 2. Hariyuddin }\end{array}$ & $\begin{array}{c}\text { Bendahara } \\
\text { 1. H. Romzil Mursidi } \\
\text { 2. Achmad Mudani }\end{array}$ \\
\hline \multicolumn{2}{|c|}{ Pembantu Umum } \\
\hline $\begin{array}{l}\text { 1. H. Abdulkadi } \\
\text { 2. H. Badrurros } \\
\text { 3. Mohammad } \\
\text { 4. Mudani Faiso }\end{array}$ & $\begin{array}{l}\text { 5. Ali Wafa } \\
\text { 6. Pamong Desa } \\
\text { lim 7. Anggota Hansip } \\
\text { 8. Juru Air Desa }\end{array}$ \\
\hline
\end{tabular}

\section{LAMPIRAN 6}

Struktur Organisasi

BAZ (Badan Amil Zakat) Putukrejo

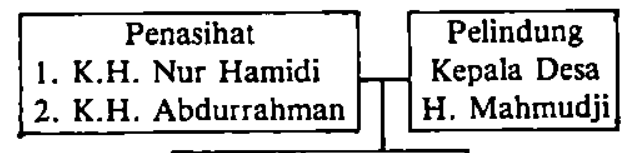
Ketua
1. K.H.A. Qasim
2. K.H. Husni

Penulis
1. Moch. Muslim
2. Ali Wafa

\begin{tabular}{|l|l|}
\hline $\begin{array}{l}\text { Sie: Penghimpunan } \\
\text { 1. Pamong Desa } \\
\text { 2. Hansip }\end{array}$ & $\begin{array}{l}\text { Sie : Pembinaan } \\
\text { 1. KH. Badaruddin } \\
\text { 2. K.H. Abu Abas }\end{array}$ \\
\hline
\end{tabular}

Sie : Pemanfaatan :

1. K.H.A. Djunaidi

2. Hariyuddin

Pembantu :

1. Moch. Soleh

2. A. Ghozali-
Pembantu :

1. H. Ali Mustofa

2. H.M. Kamal 
Hasil Pemungutan Zakat Desa Putukrejo dari Tahun 1961-1978

\begin{tabular}{|c|c|c|c|c|c|c|c|}
\hline \multirow{2}{*}{ Tahun } & \multicolumn{2}{|c|}{ Zakat Zuru' } & \multirow{2}{*}{$\begin{array}{r}\text { Zakat } \\
\text { Tijarah }\end{array}$} & \multirow{2}{*}{$\begin{array}{r}\text { Uang } \\
\text { (rupiah) }\end{array}$} & \multicolumn{2}{|c|}{ Zakat Fitrah } & \multirow{2}{*}{$\begin{array}{c}\text { Mustahic } \\
\text { (orang) }\end{array}$} \\
\hline & $\begin{array}{c}\text { Padi } \\
(\mathrm{kg})\end{array}$ & $\begin{array}{c}\text { Jagung } \\
\text { (kg) }\end{array}$ & & & $\begin{array}{c}\text { Beras } \\
(\mathrm{kg})\end{array}$ & $\begin{array}{c}\text { Jagung } \\
\text { (kg) }\end{array}$ & \\
\hline 1961 & 5500 & 2050 & & & 3450 & 1702 & 1600 \\
\hline 1962 & 6665 & 3145 & & & 4125 & 1502 & 1550 \\
\hline 1963 & 6711 & 3000 & & & 4370 & 2625 & 2400 \\
\hline 1964 & - & - & & & - & - & - \\
\hline 1965 & 7050 & 4360 & & & 4160 & 1920 & 1250 \\
\hline 1966 & 4200 & 1700 & & & 3795 & 3175 & 1200 \\
\hline 1967 & 6700 & 5000 & & & 4270 & 2350 & 1225 \\
\hline 1968 & 4211 & 5016 & & & 5720 & 1986 & 1280 \\
\hline 1969 & 4160 & 8600 & & 12.000 & 6126 & 1713 & 1300 \\
\hline 1970 & 3050 & 5116 & & 875.000 & 6500 & 1500 & 1250 \\
\hline 1971 & & & r & & & & \\
\hline 1972 & 3600 & 2950 & & & 1702 & 7852 & 1285 \\
\hline 1973 & 5000 & 4500 & & 7.019 .400 & 1906 & 8331 & 1330 \\
\hline 1974 & 6725 & 7250 & 3.500 .000 & & 2816 & 8556 & 1592 \\
\hline 1975 & 7000 & 9250 & $1: 900.000$ & & 3000 & 1250 & 1405 \\
\hline 1976 & 5000 & 4230 & 800.000 & & 2150 & 3200 & 1424 \\
\hline 1977 & 12160 & 1250 & & & 3000 & 1700 & 955 \\
\hline 1978 & 16230 & 1300 & & & 1750 & 3000 & \\
\hline
\end{tabular}

Keterangan :

- zakat fitrah $2 \frac{1}{2} \mathrm{~kg}$ per orang, dari bahan makanan orang yang berzakat (berat atau jagung).

- zakat tijarah 21/2\% (Rp. 10,00 per kwintal tebu).

- zakat zuru' 10\% (padi $12 \mathrm{kw}$, gabah kotor per nisab dan jagung $675 \mathrm{~kg}$ per nisab).

- Pembagiannya :

Zuru' .-. fakir miskin

$40 \% \quad$ Fitrah -- fakir-miskin $\quad 80 \%$

mädrasah $\quad 10 \%$ madrasah $\quad 10 \%$ amilin $\quad 10 \%$

amilin $\quad 10 \%$


Gambaran Umum Hasil Zakat Desa Putukrejo dari Tahun 1971-1978

\begin{tabular}{c|c|c|c|c|l}
\hline Tahun & $\begin{array}{c}\text { Hasil } \\
\text { Zakat } \\
(\text { Rp })\end{array}$ & $\begin{array}{c}\text { Uang } \\
\text { Desa } \\
(R p)\end{array}$ & $\begin{array}{c}\text { Laba } \\
\text { Usaha } \\
(R p)\end{array}$ & $\begin{array}{c}\text { Pengemba- } \\
\text { lian modal } \\
(R p)\end{array}$ & $\begin{array}{l}\text { Jumlah } \\
(R p)\end{array}$ \\
\hline 1971 & 2.000 .000 & 350.000 & - & - & 2.350 .000 \\
1972 & 2.000 .000 & - & 719.000 & 1.000 .000 & 3.719 .000 \\
1973 & 2.300 .000 & 350.000 & 1.350 .000 & 3.719 .000 & 7.019 .000 \\
1974 & 4.875 .000 & 1.300 .000 & - & - & 6.175 .000 \\
1975 & 1.900 .000 & 350.000 & - & - & 2.250 .000 \\
1976 & 800.000 & 350.000 & - & - & 1.150 .000 \\
1977 & 1.250 .000 & 350.000 & - &. & 1.600 .000 \\
1978 & 1.400 .000 & 550.000 & - &. & 1.950 .000 \\
\hline
\end{tabular}

\section{LAMPIRAN 9}

Grafik Penimaan Zakat Desa Putukrejo

Dari Tahun 1970-1978

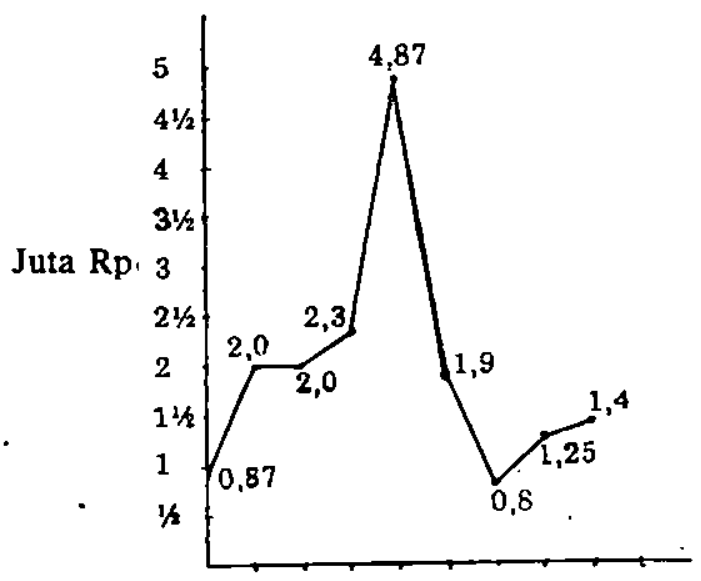

70.7172737475 76 777879

T a h u n 
LAMPIRAN 10

Penggunaan Hasil Zakat Desa Putukrejo.

Dari Tahun 1971-1978

\begin{tabular}{|c|c|c|c|}
\hline Tahun & Hasil Zakat & Dipergunakan untuk & Jumlah \\
\hline 1971 & Rp. $2.350 .000,00$ & $\begin{array}{l}\text { * diperdagangkan } \\
4 \text { buah pos Hansip } \\
2 \text { madrasah } \\
\text { alat-alat kantor. }\end{array}$ & $\begin{array}{lr}\text { Rp. } & 1.000 .000,00 \\
\text { Rp. } & 1.100 .000,00 \\
\text { Rp. } & 150.000,00 \\
\text { Rp } & 50.000,00\end{array}$ \\
\hline 1972 & Rp. $3.719 .000,00$ & $\begin{array}{l}* \text { pengerasan } 800 \mathrm{~m} \\
\text { jalan ke Ganjaran }\end{array}$ & Rp. $\quad 700.000,00$ \\
\hline 1973 & Rp. $7.019 .000,00$ & \begin{tabular}{|l} 
* 127 lembu \\
200 kambing \\
40 sepeda \\
5 mesin jahit bingkisan \\
uang a' Rp. $1.500,00$ kepada \\
68 orang
\end{tabular} & $\begin{array}{lr}\text { Rp. } & 1.100 .000,00 \\
\text { Rp. } & 1.100 .000,00 \\
\text { Rp. } & 800.000,00 \\
\text { Rp. } & 137.500,00 \\
\text { Rp. } & 102.000,00\end{array}$ \\
\hline 1974 & Rp. $6.175 .000,00$ & $\begin{array}{l}31 \text { perumahan ukuran } 5 \times 7 \mathrm{~m} \\
\text { pengerasan } 1000 \mathrm{~m} \text { jalan }\end{array}$ & $\begin{array}{l}\text { Rp. } 3.875 .000,00 \\
\text { Rp. } 2.300 .000,00\end{array}$ \\
\hline 1975 & Rp. $2.250 .000,00$ & $\begin{array}{l}5 \text { perumahan } \\
\text { pengerasan } 1200 \mathrm{~m} \text { jalan } \\
\text { madrasah }\end{array}$ & $\begin{array}{lr}\text { Rp. } & 875.000,00 \\
\text { Rp. } & 1.275 .000,00 \\
\text { Rp. } & 100.000,00\end{array}$ \\
\hline 1976 & Rp. $1.150 .000,00$ & $\begin{array}{l}\text { * pengerasan } 700 \mathrm{~m} \text { jalan } \\
\text { kesejahteaan } \\
\text { pendidikan } \\
\text { alat-alat kantor }\end{array}$ & $\begin{array}{lr}\text { Rp. } & 1.004 .500,00 \\
\text { Rp. } & 75.000,00 \\
\text { Rp. } & 50.000,00 \\
\text { Rp. } & 24.500,00\end{array}$ \\
\hline 1977 & Rp. $1.600 .000,00$ & $\begin{array}{l}\text { * gedung zakat } \\
\text { kesejahteraan } \\
\text { alat-alat kantor }\end{array}$ & $\begin{array}{lr}\text { Rp. } & 1.400 .000,00 \\
\text { Rp. } & 150.000,00 \\
\text { Rp. } & 50.000,00\end{array}$ \\
\hline 1978 & Rp. $1.950 .000,00$ & $\begin{array}{l}\text { * gedung zakat } \\
\text { kesejahteraan } \\
\text { pendidikan } \\
\text { alat-alat kantor }\end{array}$ & $\begin{array}{lr}\text { Rp. } & 1.400: 000,00 \\
\text { Rp. } & 300.000,00 \\
\text { Rp. } & 200.000,00 \\
\text { Rp. } & 50.000,00\end{array}$ \\
\hline
\end{tabular}


Rincian Penggunaan Hasil Zakat dalam Prosentase untuk kesejahteraan Masyarakat Desa Putukrejo dari Tahun 1971-1978

\begin{tabular}{|c|c|c|c|c|c|c|c|c|c|}
\hline \multirow{2}{*}{ Bidang } & \multicolumn{8}{|c|}{$T a h u n$} & \multirow[t]{2}{*}{ Bentuk } \\
\hline & 1971 & 1972 & 1973 & 1974 & 1975 & 1976 & 1977 & 1978 & \\
\hline Peribadatan & $5 \%$ & $5 \%$ & $5 \%$ & $5 \%$ & $5 \%$ & $5 \%$ & $5 \%$ & 一 & 10 langgar \\
\hline Jalan & $10 \%$ & $10 \%$ & $10 \%$ & $10 \%$ & & & & & $\begin{array}{l}5.00 \mathrm{~m} \text { penge- } \\
\text { rasan jalan }\end{array}$ \\
\hline Jembatan & $5 \%$ & $5 \%$ & $5 \%$ & & & & & & 2 buah jembatan \\
\hline Pos keamanan & $5 \%$ & $5 \%$ & $5 \%$ & & & & & & 6 buah pos \\
\hline Biaya keamanan & $2 \%$ & $2 \%$ & $2 \%$ & $2 \%$ & $2 \%$ & $2 \%$ & $2 \%$ & & 1200 orang \\
\hline Perekonomian & $25 \%$ & $25 \%$ & $25 \%$ & $25 \%$ & $25 \%$ & $25 \%$ & $25 \%$ & & 150 fakir-miskin \\
\hline Pendidikan & $10 \%$ & $10 \%$ & $10 \%$ & $10 \%$ & $10 \%$ & $10 \%$ & $10 \%$ & & $\begin{array}{l}2 \text { buah madra- } \\
\text { sah }\end{array}$ \\
\hline Perumahan & $30 \%$ & $30 \%$ & $30 \%$ & $30 \%$ & $30 \%$ & $30 \%$ & $30 \%$ & & 170 rumah \\
\hline Kesehatan & $5 \%$ & $5 \%$ & $5 \%$ & $5 \%$ & $5 \%$ & $5 \%$ & $5 \%$ & & 100 orang \\
\hline Amil & $2 \%$ & $2 \%$ & $2 \%$ & $2 \%$ & $2 \%$ & $2 \%$ & $2 \%$ & & $\begin{array}{l}\text { Administrasi/ } \\
\text { amil }\end{array}$ \\
\hline Listrik & ' & & & & & & & $20 \%$ & $\begin{array}{l}80 \text { tiang dan } \\
\text { perluasan } \\
\text { jaringan }\end{array}$ \\
\hline \multicolumn{10}{|l|}{ Lain-lain. } \\
\hline Jumlah & $100 \%$ & $100 \%$ & $100 \%$ & $100 \%$ & $100 \%$ & $100 \%$ & $100 \%$ & $100 \%$ & \\
\hline
\end{tabular}




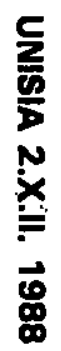

LAMPIRAN 12

Grafik Perkembangan Zakat Desa Putukrejo $\mathrm{Z}$ a k a t - T a h u n

Kepala Keluarga

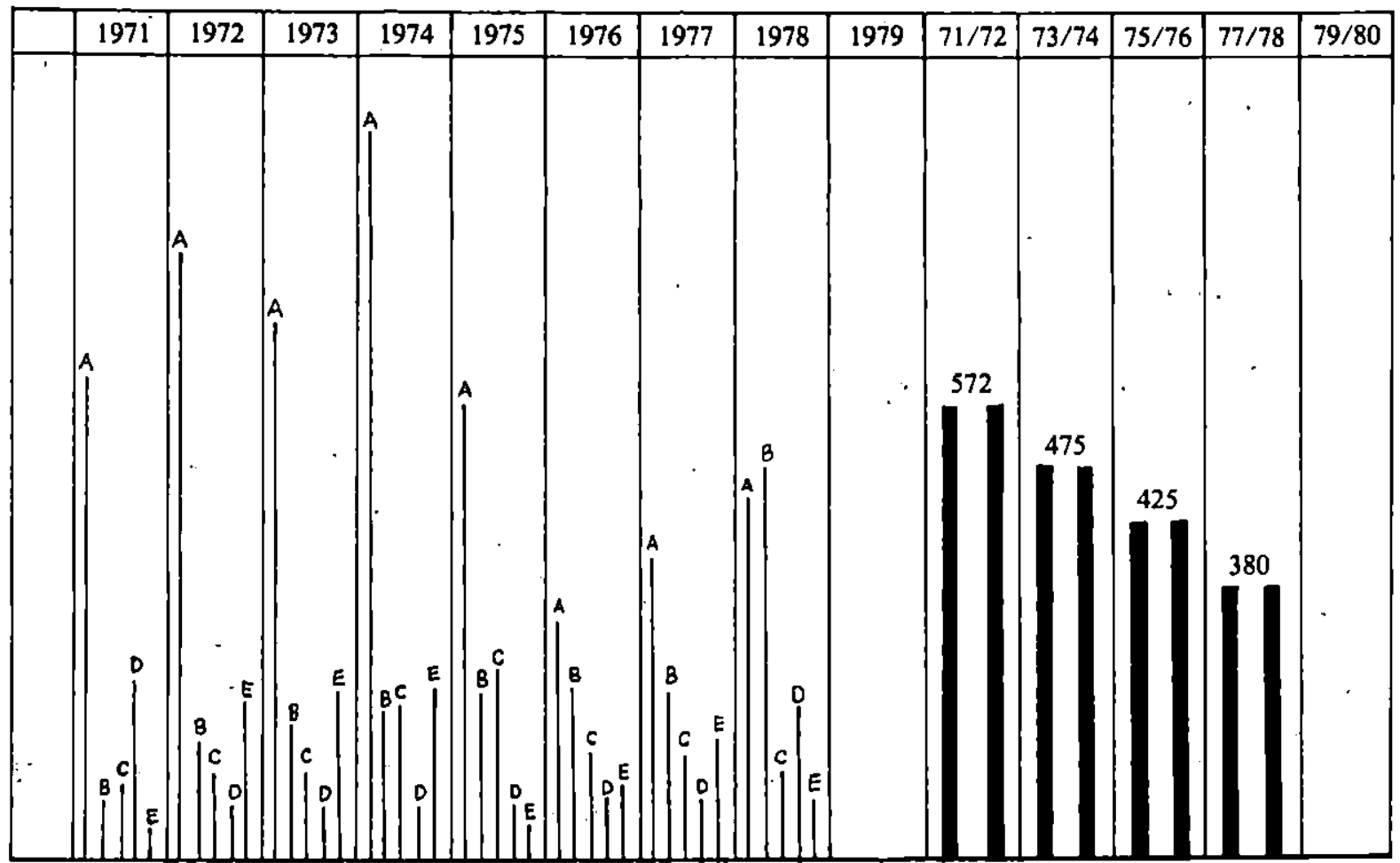

